\title{
Dealing with Egypt Public Debt Accumulation Problem
}

\author{
Mohammed I. Abdu \\ Economist at Arab Republic of Egypt Ministry of Finance, The Arab Republic of Egypt \\ E-mail: Mohammedibrahimabdu@gmail.com
}

The views expressed in this Paper are those of the author and do not necessarily represent the organization he works for

Received: October 4, 2019 Accepted: October 26, 2019 Published: November 3, 2019

doi:10.5296/ber.v9i4.15569 URL: https://doi.org/10.5296/ber.v9i4.15569

\begin{abstract}
This paper examines the public debt problem in Egypt, and provides new supportive and non-stereotyped ideas that could help to put public debt on a downturn and a sustainable pass. The analytical approach was used to identify the magnitude of the public debt problem through analyzing the debt structure, the increase in interest payments, and private investment crowding out. The study also evaluates the impact of the economic reform problem on the debt to GDP level; in addition to analyzing the implications of the government plan on debt structure and its associated risks. Some of these risks are: the unsustainability of GDP growth and its structure, debt roll over risk, and the risk of materializing contingent liabilities. Furthermore, this paper proposes new ideas; besides, the usual concentration on fiscal consolidation and stable economic growth to decrease the Egyptian public debt. Improving tax collection, developing government securities market, using the appropriate economic policy mix, applying zero interest rate on the government liabilities to the Central bank of Egypt, and swapping debt with equity, are some non-stereotyped ideas that could help in reducing the public debt of Egypt.
\end{abstract}

Keywords: Debt reduction, Egypt's public debt, Fiscal consolidation, and economic reform program

\section{Introduction}

Accumulating public debt has become a global phenomenon, reflecting developed countries policy response to economic collapse throughout the time of the global financial crisis, while it reflects the effects of the fall in commodity price that started in 2014, in addition to the rapid spending growth, when it comes to emerging markets and low income developing countries.

In advanced economies, average debt to GDP ratio is $105 \%$; such levels haven't been seen 
since the Second World War and expected to decrease partially on the medium term. On the other hand, the debt to GDP ratio in middle income economies countries and emerging markets is close to $50 \%$ on average; these levels were last seen during the debt crisis in the 1980s and expected to continue on the upward trend. On the contrary, the debt to GDP ratio for low income developing countries have been increasing rapidly to reach $40 \%$ in 2017 , and it is not expected to decrease much over the medium term.

The high government debt and deficits raised a lot of concerns. Countries with high debt could be subject default and rollover shocks because of the large increase in gross financing needs. Furthermore, high public debt and deficit hinder governments from applying sufficient fiscal policy in the occurrence of a downturn (International Monetary Fund [IMF], 2018). In addition, infinite increase of public debt hurts economic growth and crowed out private investment.

The current increase in public debt has brought to the forefront of the discussions the sustainability of public debt and fiscal policies. The concept of debt sustainability concentrates on the consistency of a number of macroeconomic variables and polices that keeps debt stable. This means that countries will not be subject to default or apply large fiscal adjustment or debt restructuring (United Nations Conference on Trade and Development [Unctad], 2018).

Currently, there is no agreement on a particular threshold for the public debt level beyond which the economic growth will be affected sharply (Pescatori, Sandri, \& Simon, 2014). However, the IMF's debt sustainability analysis identifies a critical threshold beyond which the debt sustainability become subject to high risk. Since the debt sustainability analysis for market accesses countries identifies the threshold for advanced and emerging market economies as $85 \%$ and $70 \%$ of GDP respectively; while the IMF and World bank joint debt sustainability framework for low income countries identifies the critical threshold as $75 \%$, $62 \%$, and $49 \%$ of GDP, depending on the institutional quality within the country (IMF, 2018).

Abbas, et al. (2013) study, which analyzes 26 episodes of large debt reversals since the 1980s in advanced economies, argues that the decrease of debt was frequently associated with strong primary balances and higher growth rates; while interest rates, inflation, and stock flow adjustment affected also debt dynamics, but with a relatively minor roles.

On the other hand, Reinhart and Rogoff (2015) explore the options for renormalizing the levels of public debt through examining 70 episodes from 1800 to 2014 across 22 advanced economies where there were sustained and significant reduction in public debt as percentage of nominal GDP. The paper classifies the strategies for debt reduction basically to two categories. The first category is the orthodox options that typically make up the core of IMF and its partners programs. Orthodox options mainly include increasing the economic growth, fiscal consolidation and running primary budget surplus, and privatization of government assets. The second category is heterodox polices that include generating unexpected inflation, restructuring debt contracts, repressing private finance, and taxing wealth.

The paper argues that there are many options on the list for governments to choose from for 
bringing down debt, not only tightening budget, and it's very crucial for policymakers when debt reaches a high and rising levels to be aware of the whole range of options, whether they are orthodox or heterodox; as the study found that advanced countries have relied more on the heterodox approaches to reduce their debt.

Egypt's general government debt reached a precarious level in June 2017, and recorded 103.1\% of the GDP. Despite the decrease of this percentage to $92.5 \%$ in June 2018, it's still an alarming level of debt to GDP ratio. This critical level of debt reflects the long-standing macroeconomic and fiscal imbalances, and the insufficient use of traditional tools to deal with the imbalance in public finance and debt balance through the government economic reform program, that was approved by the IMF in November 2016.

A number of studies dealt with the public debt problem in Egypt, but most of them concentrated on analyzing the impact of public debt on economic growth; like ElGhouty (2018) study, which tried to examine the reasons behind the increase in public debt, after the 25 th of January revolution; in addition to analyzing the economic growth performance, and the relationship between public debt and economic growth. El-Mahdy and Torayeh (2009) study, also examined domestic public debt sustainability in Egypt for the period 1981-2006, and analyzed the impact of this domestic public debt on economic growth.

There are other studies that aimed at forecasting the magnitude of Egypt's public debt, and/or assessing its sustainability. In that regards, Aiba, Al-shawarby, and Iqbal (2004) study assessed fiscal and public debt sustainability in Egypt, and analyzed the key fiscal trends underlying the growth in public debt; while Massoud (2014) paper provided a forecast for the size of Egypt's public debt under various scenarios.

Furthermore, some studies endeavored to assess the main drivers of Egypt's debt accumulation; for instance, Alnashar (2019) study, which argued that exchange rate depreciation is as important as primary deficit in government debt accumulation; while Fayed (2012) study tried to measure the impact of public borrowing on crowding out private credit.

Studies mentioned above, and most of the studies about Egypt's public debt, mainly focused on the reasons behind the accumulation of public debt, its projections, and assessment of its sustainability in the foreseeable future; in addition to introducing traditional policies to deal with this phenomenon; including, fiscal consolidation and increasing economic growth. However, this study aimed to introduce new supportive and non-stereotyped ideas that could help in putting public debt in Egypt on a downturn and sustainable pass; as, it is based on a deep analysis to public debt structure, and a solid understanding of the intergovernmental linkages between public debt and its macroeconomic determinants.

Despite the fact that the economic reform program has helped to decrease the debt/GDP ratio, the debt absolute amount still accumulating, and it has a negative impact on the debt structure; since, the external component has grown to $20.7 \%$ in June 2018 , after it was $8.2 \%$ before June 2016. On the other hand, the short term debt, namely the domestic T-bills, has grown from $33.9 \%$ in June 2016 to $47.5 \%$ in June 2018.

The chronic imbalance in fiscal position, in addition to the negative changes in debt structure, 
has affected the future increase in the debt service; since, the interest payments has grown from about $15 \%$ of total budget expenses in $2008 / 2009$ to $35.2 \%$ in $2017 / 2018$, and is expected to exceed $38 \%$ in the fiscal year $2018 / 2019$.

This accumulated balance of debt, and further financing needs to service it, have a direct negative impact on the private investment; as, it increases the interest rate in the market and crowds out productive investments; especially when the banking sector invests a considerable part of its assets in government securities.

In that regards, the basic hypothesis for this paper is that government policies to reduce public debt in Egypt to a convenient level weren't enough and have a negative impact on debt structure. In addition, the government corresponding policy to the increase in public debt levels was so classic and needs supportive non-stereotyped measures to deal with this accumulating mount of debt and to reduce the debt service burden which reached a critical level and became a source of the growing public debt.

In spite of the ongoing fiscal consolidation, combined with further increase in GDP growth that leads to a decrease in the debt/GDP ratio, more efforts are needed to meet the targets of medium term debt management strategy (2015/2016 - 2017/2018), and the five year's macroeconomic framework and strategy (2014/2015 - 2018/2019). Moreover, the debt sustainability in Egypt is subject to significant risks.

Fiscal consolidation will continue to be on the top of the fiscal agenda list in Egypt over the coming years. However, due to the fact that there aren't much fiscal measures on the list to be applied, and regarding the structure of Egypt's public debt, and its intergovernmental linkages and macroeconomic determinants, new supportive and non-stereotyped ideas should be applied, in order to put Egypt's public debt on a downturn and a sustainable pass.

\section{The Magnitude of the Problem}

Higher and increasing debt levels have a negative impact on the country's economy, as it leads to higher debt service and a vicious cycle between growing debt and debt service. It also deprives productive investment of funds, and decreases the potential GDP growth (Organization for Economic Cooperation and Development [OECD], 2013).

The higher the level of public debt, the higher the primary surplus needed to sustain it; which most likely made the fiscal policy and public debt unsustainable. Moreover, the high public debt, associated with higher interest rate and low growth rates, requires higher primary balance to service it.(Alba et al, 2004).

Since 2011, the problem of public debt was aggravated by low GDP growth, large fiscal deficits, and external fragility reflected on the international reserves and exchange rate; therefore, it is considered a chronic problem in the Egyptian economy. (IMF, 2015).

The increase in public expenditures is considered the main source of public debt increase in Egypt; especially after 2011, when the increase in government expenditures was accelerating more than the revenues that were reflected on the budget deficit. After the 2011 revolution, the revenues, especially taxes, were affected seriously due to the economic downturn; which 
was a result to unstable political and social states. In addition, there was a significant hike in expenditures mainly; salaries, subsidies, interest payments and public investments. (ElGhouty, 2018).

The two digit fiscal deficit for five years, the structure of public debt itself, and a number of economic reform program items; such as, local currency devaluation and the shift to more dependence on foreign debt; especially with the ongoing increase in the interest rate on the global market of bonds, were reflected on an increase in debt services, and the interest payment became the highest item of public expenditure, and the main source of the budget deficit.

\subsection{Debt Structure}

Understanding the definition of public debt and its components is important, in order to identify its drivers, and how to deal with the problem. In that sense, this section will provide a deep analysis to the current situation of public debt and its drivers (Aiba et al, 2004).

\subsubsection{Domestic and External Debt}

Egypt's Ministry of Finance (Mof), Financial Monthly Bulletin, sorts the Debt to Domestic Public Debt and Gross External Debt. There are other two levels of domestic debt; General Government Debt and Domestic Budget sector Debt. Furthermore, the Gross External Debt has two major components; Gross External Government Debt and Gross External Non-Government Debt.

The Domestic Budget sector Debt is defined as the outstanding domestic debt stocks due on Central Administration, local Government, and Public Service Authorities. On the other hand, the Domestic General Government Debt is calculated as the addition of domestic budget sector debt, National Investment Bank (NIB), and Social Insurance Fund (SIF). This level is deducting budget sector borrowing from the Social Insurance Fund, National Investment Bank, and National Investment Bank borrowing from the Social Insurance Fund.

In addition, the Domestic Public Debt consists of domestic debt due on General Government and the debt due on Economic Authorities. This level excludes outstanding debt of Economic Authorities to National Investment Bank, and the borrowing of Budget Sector from Economic Authorities. (Arab Republic of Egypt Ministry of Finance [Mof], 2018).

So, The Gross General Government Debt is calculated as follows:

Domestic Government Debt + External Government Debt $=$ Gross General Government Debt (1)

In September 2015, the Ministry of finance launched its Medium-Term Debt Management Strategy (MTDS), which was planned to operate over three fiscal years from 2015/2016 to 2017/2018. This strategy stated clearly Egypt's intention of increasing the amount of foreign currency borrowing gradually. However, it acknowledges that increasing foreign debt significantly is not considered the best solution, even at attractive global rates. Nevertheless, the Ministry of finance aims, from this trend, to reduce the cost of borrowing by filling part 
of the financing gap through the external markets (Mof, 2015).

Figure (1) shows that the Ministry of finance intention of financing its needs from external market is reflected in the share of external debt in the structure of debt itself; since, it was raised from $8.2 \%$ in June 2016 to $20.7 \%$ in June 2018. On the other hand, this increase in the share of external debt in the debt structure shouldn't be explained only by the increase of the external governmental debt (from 24.4 billion USD in June 2016 to 47.7 billion USD in June 2018). As, there was another important factor that amplified the effect; which was the devaluation of the Egyptian pound in the $3^{\text {rd }}$ of November 2016.

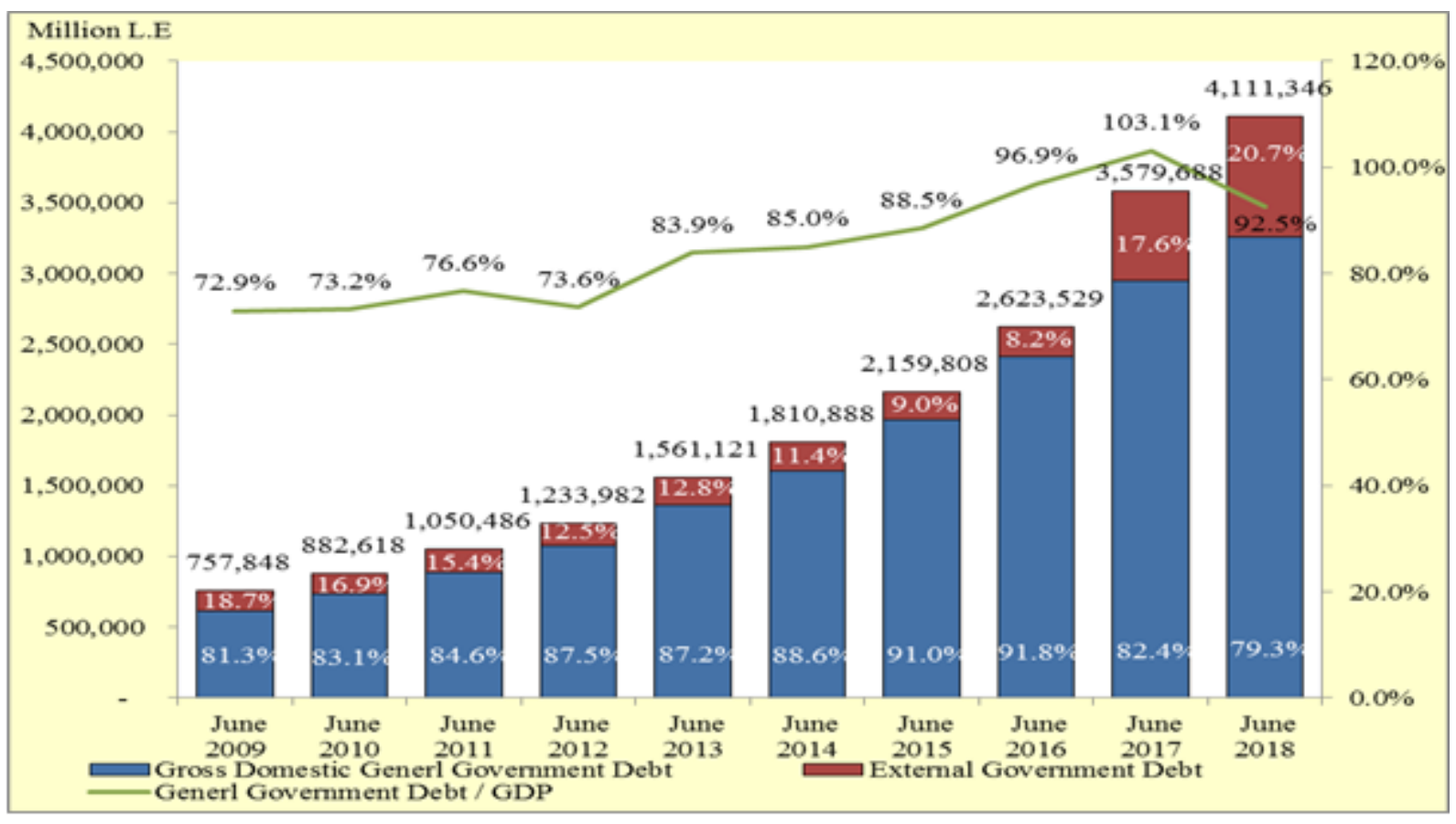

Figure 1. General Government Gross Debt from June 2009 to June 2018

The source of data: Arab Republic of Egypt Ministry of finance, The Financial Monthly Bulletin, Number of volumes.

The devaluation of the Egyptian pound was an important procedure of the Economic Reform Program; which was approved by the IMF to eliminate foreign exchange shortage, and restore confidence in the economy. This step was supported by a strict monetary policy to contain inflation expectations, contain external and domestic demand, and facilitate building up international reserves. While this step helped to restore foreign exchange flow to banks, the Egyptian pound depreciated larger than it was initially expected. This was also reflected on inflation, which recorded $32.8 \%$ in 2016/2017, when the IMF projections were $16.6 \%$. Although the inflation rate started to decrease, the potential risk is becoming clear about Egypt mounting external debt (IMF, 2016).

After 2011, the total External Debt has started to grow rapidly. In June 2011, the total external debt was 34.91 billion US dollars; then it increased to become more than 92.64 billion US 
dollars in June 2018. The external debt to GDP ratio has also grown in the same period from $15.2 \%$ in June 2011 to $37.2 \%$ in June 2018. This increase in external debt was reflected on external debt indicators. Since, the external debt to export ratio grew to $195.8 \%$, short term debt to external debt reached $13.3 \%$, short term debt to net internal reserve reached $27.8 \%$, debt service reached 13.2 billion US dollars, debt services to exports became about $28 \%$, debt services to current receipts became 17.7 , interest to exports ratio became 4.6, and external debt per capita grew to 883.9 US dollars.

Table 1. External Debt Indicators from June 2009 to June 2018

\begin{tabular}{|l|l|l|l|l|l|l|l|l|l|l|}
\hline Indicators & $\begin{array}{l}\text { June } \\
2009\end{array}$ & $\begin{array}{l}\text { June } \\
2010\end{array}$ & $\begin{array}{l}\text { June } \\
2011\end{array}$ & $\begin{array}{l}\text { June } \\
2012\end{array}$ & $\begin{array}{l}\text { June } \\
2013\end{array}$ & $\begin{array}{l}\text { June } \\
2014\end{array}$ & $\begin{array}{l}\text { June } \\
2015\end{array}$ & $\begin{array}{l}\text { June } \\
2016\end{array}$ & $\begin{array}{l}\text { June } \\
2017\end{array}$ & $\begin{array}{l}\text { June } \\
2018\end{array}$ \\
\hline $\begin{array}{l}\text { Total External Debt } \\
\text { (Billion US\$) }\end{array}$ & 31.53 & 33.69 & 34.91 & 34.38 & 43.23 & 46.07 & 48.06 & 55.76 & 79.03 & 92.64 \\
\hline External Debt/GDP \% & 16.9 & 15.9 & 15.2 & 12.4 & 16.3 & 15.5 & 15.0 & 18.3 & 41.1 & 37.2 \\
\hline $\begin{array}{l}\text { External Debt Growth } \\
\text { rate\% } \%\end{array}$ & -7.0 & 6.9 & 3.6 & -1.5 & 25.7 & 6.6 & 4.3 & 16.0 & 41.7 & 17.2 \\
\hline $\begin{array}{l}\text { External Debt/Exports } \\
\text { (Annually) \% }\end{array}$ & 64.4 & 71.0 & 71.4 & 74.8 & 88.2 & 106.0 & 109.1 & 160.3 & 212.9 & 195.8 \\
\hline $\begin{array}{l}\text { Short-term Debt/External } \\
\text { Debt \% }\end{array}$ & 6.8 & 8.8 & 7.9 & 8.5 & 16.3 & 7.9 & 5.4 & 12.6 & 15.5 & 13.3 \\
\hline $\begin{array}{l}\text { Short-term Debt/Net } \\
\text { International Reserves \% }\end{array}$ & 6.8 & 8.4 & 10.4 & 18.7 & 47.2 & 21.9 & 12.8 & 40.0 & 39.2 & 27.8 \\
\hline $\begin{array}{l}\text { Debt Service } \\
\text { (US\$ Billion) }\end{array}$ & 3.1 & 2.6 & 2.8 & 2.9 & 3.1 & 3.2 & 5.6 & 5.1 & 7.3 & 13.2 \\
\hline Debt Services/Exports & 6.4 & 5.5 & 5.7 & 6.3 & 6.3 & 7.4 & 12.7 & 14.6 & 19.7 & 28.0 \\
\hline $\begin{array}{l}\text { Debt Services/Current } \\
\text { Receipts }\end{array}$ & 5.5 & 4.5 & 4.5 & 4.5 & 4.5 & 4.3 & 8.5 & 9.8 & 12.3 & 17.7 \\
\hline Interest/Exports & 1.5 & 1.4 & 1.3 & 1.4 & 1.3 & 1.6 & 1.5 & 2.4 & 3.3 & 4.6 \\
\hline $\begin{array}{l}\text { External Debt per Capita } \\
\text { (US\$) }\end{array}$ & 418.6 & 399.2 & 413.6 & 387.7 & 475.3 & 506.4 & 513.5 & 573.1 & 754.1 & 883.9 \\
\hline
\end{tabular}

The Source of data: Central Bank of Egypt, External Position of the Egyptian Economy, Number of volumes; Arab Republic of Egypt Ministry of finance, The Financial Monthly Bulletin, Number of volumes.

All these indicators show that the external debt in Egypt reached a critical point. The most important concern is that external debt is expected to continue growing in the coming year, which could put a lot of doubt on the financial stability in Egypt.

\subsubsection{Short and Long Term Debt}

The structure of domestic debt has undergone significant change since June 2016; this could be clearly seen from figure (2). The short term component has more than doubled, exceeding $47 \%$ of the growth domestic general government debt. This increase in short term domestic debt is a result of the two digit budget deficit for more than five years in this decade, which was financed heavily through short term government securities.

Figure (2) also shows that T-bills issuance has increased steadily during this decade, recording 2631 billion Egyptian pounds in the fiscal year 2017/2018; which represents 59.3\% of the GDP. Meanwhile, the increase of the issuance reached its highest growth rate, which 
was $28.1 \%$ and $27.8 \%$ in the financial years $2016 / 2017$ and $2017 / 2018$, respectively. This trend has led to a large and growing financing needs requirement to roll over the debt in the short-term and become a source of potential risk; whenever the financing conditions deteriorate in Egypt (Mossallem, 2017).

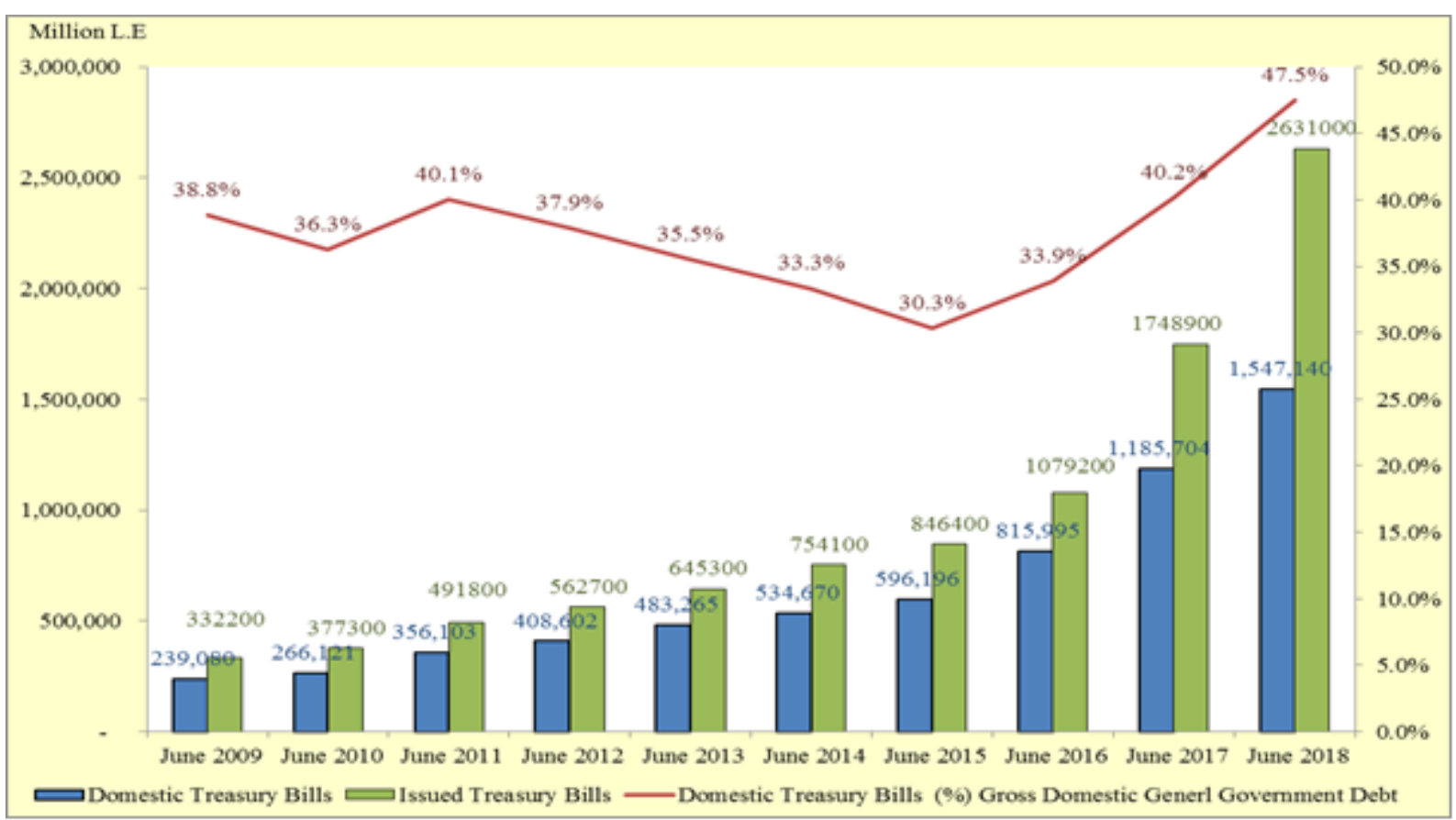

Figure 2. Issued and Outstanding Domestic Treasury Bills from June 2009 to June 2018

The source of data: Arab Republic of Egypt Ministry of finance, The Financial Monthly Bulletin, Number of volumes.

\subsection{The Increase in Interest Payments}

This high debt level in Egypt was combined with a tight monetary policy by the central bank, to curb the inflationary effect of austerity measures; especially the energy subsidy reform and the currency depreciation (IMF, 2018).

The high debt Egyptian burden is reflected in higher cost to service it. In the fiscal year $2017 / 2018$, interest payments absorbed about 35\% of the budget, and it's projected to consume $38 \%$ of the budget for fiscal year 2018/2019; as it is expected to eat up almost $55 \%$ of total government revenues.

Figure (3) shows that interest payment, as parentage of the total expenditures, has grown rapidly from around $15 \%$ in fiscal year 2008/2009 to $38 \%$ in the budget for the fiscal year 2018/2019.

In the same trend, the interest payment has increased tremendously as percentage to both total revenues and GDP. Interest payments, as percentage of GDP, increased from $4.8 \%$ in fiscal year $2008 / 2009$ to $10.3 \%$ in fiscal year 2018/2019 budget. Meanwhile, interest payment, as 
percentage of total revenues, increased from $18.7 \%$ in fiscal year $2008 / 2009$ to $54.7 \%$ in the fiscal year 2018/2019 budget.

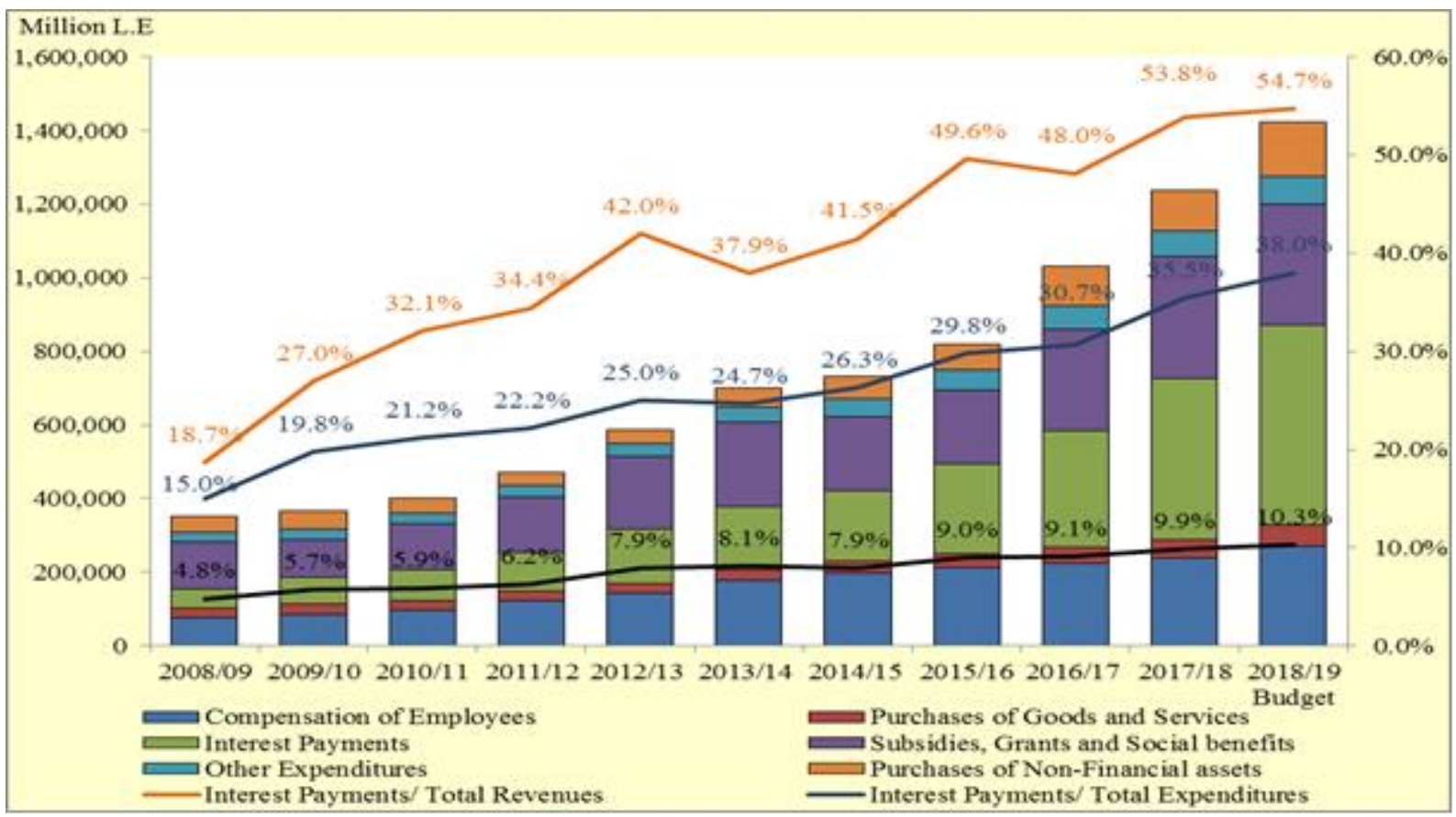

Figure 3. Interest Payment from 2008/09 to June 2017/2018

The source of data: Arab Republic of Egypt Ministry of finance, The Financial Monthly Bulletin, Number of volumes.

Debt service costs in the foreseeable future will continue to increase; due to the following factors:

- Rising global interest rates, and a stronger dollar, have pushed up financing costs for Egypt and other emerging markets.

- The Ministry of finance is planning to issue three to seven billion USD of international bonds in 2019 (Commercial International Bank [CIB], 2019).

- The borrowed funds are not being invested; so, they are not generating adequate returns, and they are used to finance the budget deficit, and to build the international reserve (IMF, 2018).

- The accumulation of debt and the two digit interest rate in the local market.

\subsection{Crowding Out Private Investment}

Public debt level in Egypt has important implications on investment (Massoud, 2014). Since, it increases the domestic interest rates, which crowds out private investment. On the other hand, it affects the behavior of the banking sector through the tendency of investment in government securities; rather than lending the private sector productive investment 
(Abdel-Khalek, 2007).

Figure (4) shows that government securities represent a considerable part of the securities portfolio of the banking sector; since, it recorded $95.3 \%$ in June 2015, but decreased slightly to register $94 \%$ in June 2018. On the other hand, total credit facilities for the government has grown steadily over this decade; since, it represented about $7.2 \%$ of the total Banking sector credit facilities in June 2009, and grown to register $27.8 \%$ in June 2018. Overall, the accumulation of Government Securities and Credit Facilities represented about $40.1 \%$ of the banking sector assets in June 2018, while it recorded its highest level in June 2016 by $49.1 \%$.

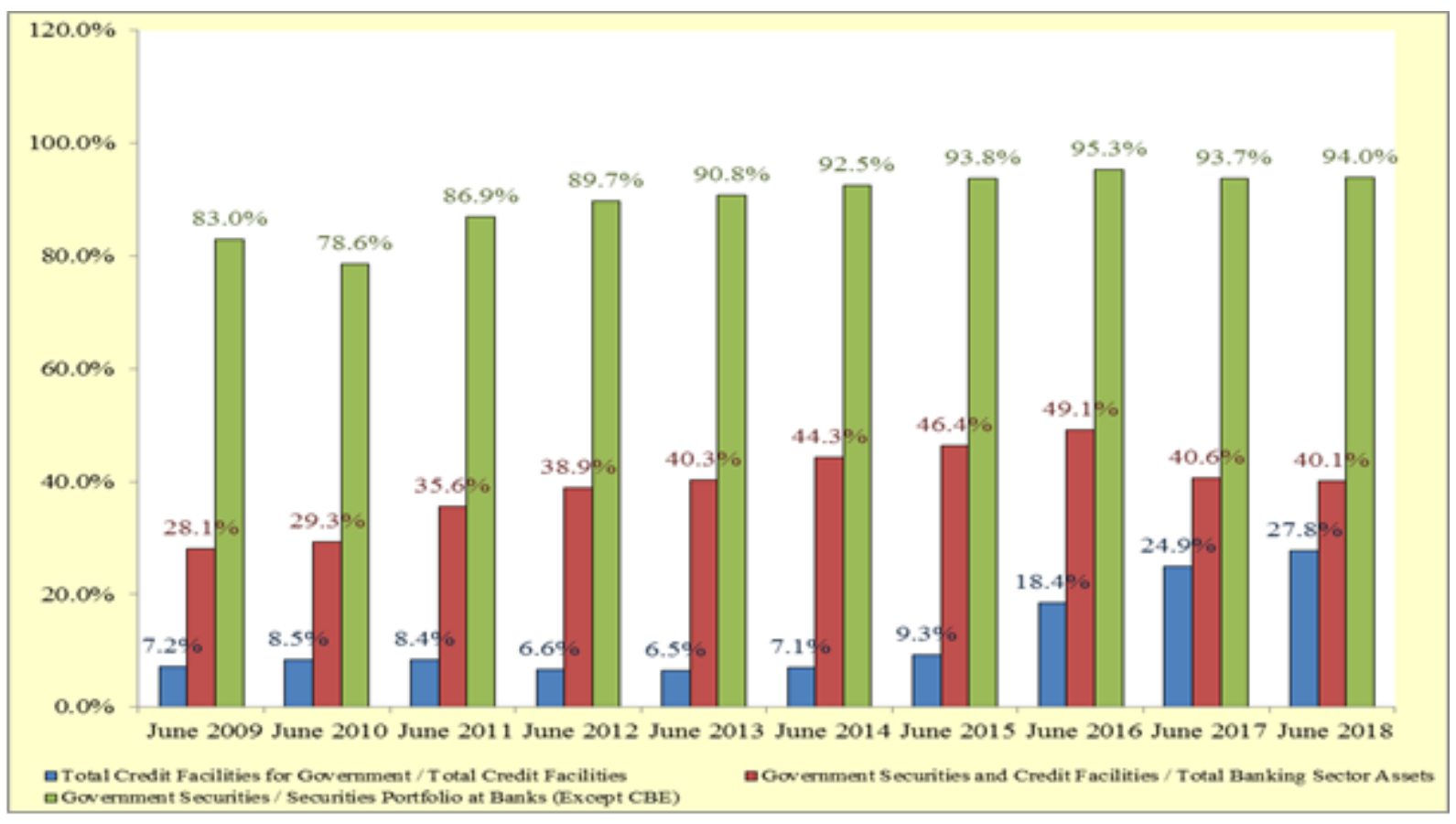

Figure 4. Banking Sector Securities and Credit Facilities to the Government from June 2009 to June 2018

The source of data: Central Bank of Egypt, Monthly Statistical Bulletin, Number of volumes.

Table 2. Average Interest Rates on Government Securities from 2009/2010 to July-December 2018/2019

\begin{tabular}{|l|l|l|l|l|l|l|l|l|l|l|}
\hline $\begin{array}{c}\text { Average Interest } \\
\text { Rates }\end{array}$ & $\begin{array}{l}2009 / \\
2010\end{array}$ & $2010 /$ & $\begin{array}{l}2011 / \\
2012\end{array}$ & $\begin{array}{l}2012 / \\
2013\end{array}$ & $\begin{array}{l}2013 / \\
2014\end{array}$ & $\begin{array}{l}2014 / \\
2015\end{array}$ & $\begin{array}{l}2015 / \\
2016\end{array}$ & $2016 /$ & $\begin{array}{l}2017 / \\
2018\end{array}$ & $\begin{array}{l}\text { July-December } \\
2018 / 2019\end{array}$ \\
\hline 91 Day T_Bills & 9.9 & 11.5 & 13.1 & 13.3 & 10.9 & 11.4 & 11.8 & 17.5 & 18.8 & 19.4 \\
\hline 182 Day T_Bills & 10.2 & 11.8 & 14.1 & 14.0 & 11.3 & 11.7 & 12.3 & 18.1 & 18.8 & 19.6 \\
\hline 273 Day T_Bills & 10.5 & 11.4 & 14.8 & 14.3 & 11.4 & 11.8 & 12.5 & 18.3 & 18.3 & 19.6 \\
\hline 364 Day T_Bills & 10.5 & 11.5 & 14.8 & 14.4 & 11.5 & 11.9 & 12.5 & 18.2 & 18.1 & 19.5 \\
\hline Bonds & N/A & N/A & 15.3 & 15.5 & 12.8 & 12.9 & 13.5 & 16.9 & 16.1 & 18.7 \\
\hline
\end{tabular}

The Source of data: Arab Republic of Egypt Ministry of finance, The Financial Monthly Bulletin, Number of volumes. 


\section{Macrothink}

Business and Economic Research

ISSN 2162-4860

2019, Vol. 9, No. 4

The high inflation rate, close to $40 \%$, was the direct result of the Egyptian pound devaluation in $3^{\text {rd }}$ November 2016, to reflect the loss in the purchasing power of the pound against the US dollar. The Central Bank of Egypt (CBE) reaction to this inflationary wave was so classic; since, it raised the interest rate by 300 to absorb the excess liquidity; however, inflation remained in a bullish direction (Central Bank of Egypt [CBE], 2017).

This policy has a direct impact on the economy; this includes:

- The increase in domestic debt services bill, which increased from about $30.7 \%$ in the fiscal year 2016/2017 of the total expenses to exceed $35 \%$ in $2017 / 2018$, as shown in figure (3) (Iradian \& Rosenthal, 2018).

- The high interest rate, which has a negative impact on investment; as, what type of project could generate an income close to $20 \%$ interest granted by commercial banks free of risk, either on savings certificates or treasury bills? This policy has a serious effect on investment, while reduction in investment leads to a decline in production, and consequently, a decrease in the supply of goods and services, which leads to higher inflation, assuming demand is stable in the short term.

The crowding out of the private sector could be shown clearly from figure (5). Although private sector investment returns to positive growing, since the fiscal year 2013/2014, to reach 316.4 Billion Egyptian Pound in the fiscal year 2017/2018; which means 3.3 times of its amount in 2008/2009, the share of private investment has dramatically decreased from $61.8 \%$ of total investment in $2010 / 2011$ to about $41.5 \%$ in $2016 / 2017$, and improved slightly in $2017 / 2018$ to reach $43.9 \%$ in $2017 / 2018$.

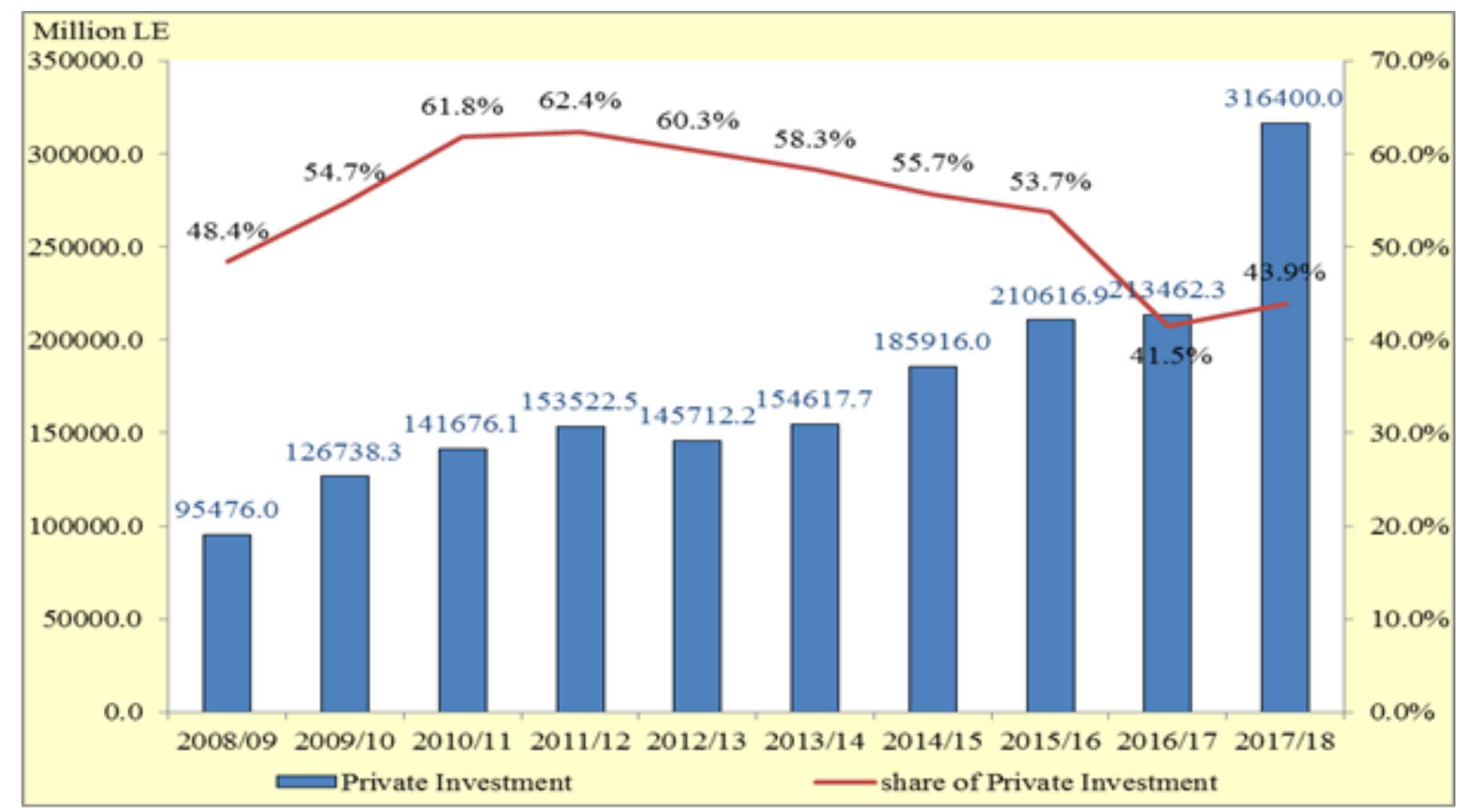

Figure 5. Private Sector Investment from 2008/2009 to 2017/2018

The source of data: Ministry of Planning Monitoring and Administrative Reform, Database. 


\section{Government Plan of Debt Sustainability}

Strong fiscal consolidation to put debt on a declining path toward more sustainable levels is one of the four key pillars of Egypt economic reform program. To sustain public debt, the government focuses on the following key policy measures:

- $\quad$ Fiscal consolidation; through enhancing revenue mobilization, mainly by introducing VAT law, improving tax administration, optimizing expenditure through public financial measures, reducing subsidies, and controlling public sector wages bill.

- Improving business climate to promote growth, which will have important implications on the medium term public debt sustainability.

- Lengthening the maturity of the domestic tradable debt, and reducing the risk of refinancing through consolidating the domestic yield curve (IMF, 2016).

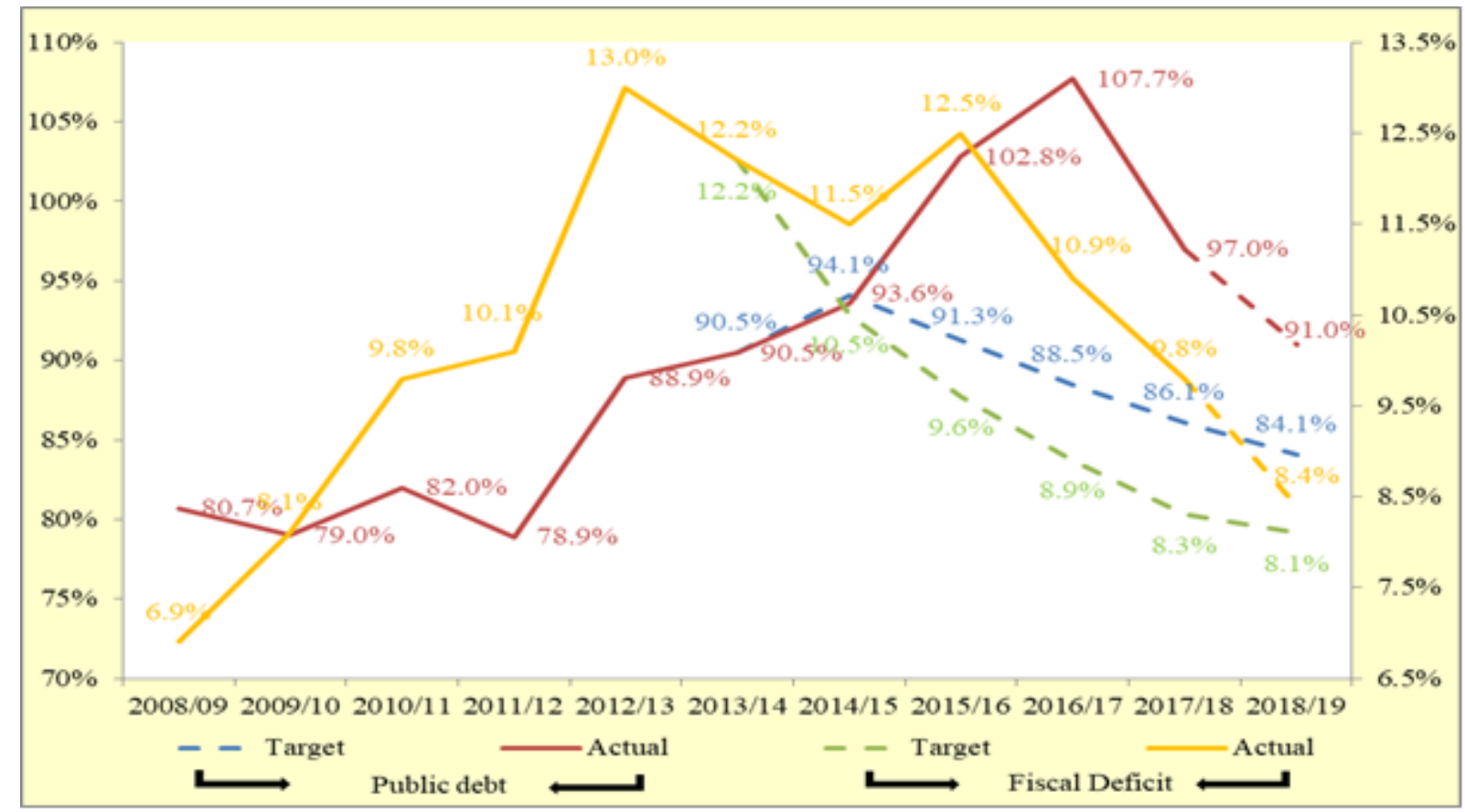

Figure 6. Fiscal Deficit and Debt to GDP Ratio from 2008/2009 to 2018/2019

The source of data: Ministry of Finance, Financial Statement, 2018/2019; Government of Egypt, Start-EGY (Egypt's Five Year Macroeconomic Framework and Strategy FY14/15 - FY18/19), Egypt Economic Development Conference, Sharm El-Sheikh, March 2015.

The Ministry of finance proclaims through its medium term debt management strategy (MTDS), decreasing budget deficit to $8-8.5 \%$ of GDP, and government debt to $80-85 \%$ of GDP by the fiscal year 2019/2020 (Mof, 2015). Despite the ongoing fiscal consolidation, combined with further increase in GDP growth, these efforts weren't enough to meet the targets of medium term debt management strategy (2015/2016 - 2017/2018), and the five year macroeconomic framework and strategy (2014/2015 - 2018/2019) (Iradian \& Rosenthal 
2018).

Figure (6) shows clearly that policy measures, taken by the government, weren't enough to meet the ambitious targets that aim to reduce budget deficit and public debt. Meanwhile, the closing account, for the fiscal year 2017/2015, shows that fiscal deficit and debt to GDP ratios were higher than their targets by $1.5 \%$ and $10.9 \%$ of the GDP, respectively.

On the other hand, the IMF four reviews for Egypt's economic reform program referred to the declining of Debt/GDP ratio, and projected further decline over the medium term; due to the significant growth of nominal GDP and the authorities' fiscal consolidation efforts. Regarding the most favorable scenario, (the baseline scenario), in the fourth review, Egypt's economy will still need higher scrutiny debt sustainability analysis; since the Debt/GDP and Financing needs/GDP ratios are projected to remain above the benchmark of 50\% and $10 \%$ for the emerging market countries by the end of program and on the medium term. This could be seen from table (3) (IMF, 2013).

Table 3. IMF projections to public debt and financing need as a ratio of GDP

\begin{tabular}{|l|l|l|l|l|l|l|}
\hline & 2019 & 2020 & 2021 & 2022 & 2023 & 2024 \\
\hline Nominal gross public debt & $86.0 \%$ & $83.3 \%$ & $80 \%$ & $77.9 \%$ & $74.2 \%$ & $71.4 \%$ \\
\hline Public gross financing needs & $36.2 \%$ & $31.9 \%$ & $35.3 \%$ & $36.4 \%$ & $37.5 \%$ & $38.3 \%$ \\
\hline
\end{tabular}

The Source of data: IMF, Arab Republic of Egypt, Fourth review under the extended fund facility, Country Report No. 19/98, April 2019.

Despite the fact that the IMF reviews to Egypt's economy indicate the debt is sustainable, due the significant decrease in Debt/GDP ratio in the last Fiscal year, and the further targeted decrease in this ratio on the medium term, debt sustainability in Egypt is subject to significant risks:

\subsection{Economic Growth Structure and Sustainability}

Despite the favorable impact of the economic reform program in narrowing the fiscal deficit and decreasing the debt/GDP ratio, it has an unfavorable consequence on the majority of population; due to the sharp increase in the cost of living, which has a direct impact on people purchasing power, and subsequently the households consumption. This decrease in household consumption directly affects the GDP growth; while it is one of the most important drivers of growth in Egypt (Ghafar, 2018).

Figure (7) shows clearly that economic reforms have affected the contribution of final consumption in GDP growth; as, it was decreasing steadily over the last decade from about $4.6 \%$ in the fiscal year 2008/20009 to almost $1.1 \%$ in the fiscal year 2017/2018. Further economic measures are expected to be applied before the end of the fiscal year 2018/2019, especially on fuel price to achieve cost recovery. This might further reduce households' welfare, and subsequently, the final consumption and economic growth. Therefore, there is a risk from the ongoing fiscal consolidation on the targeted growth and debt sustainability. 


\section{Macrothink}

Business and Economic Research

ISSN 2162-4860 2019, Vol. 9, No. 4

Figure (8) shows that Real Estate sector has grown from 2.7\% in the fiscal year 2008/2009 to $10.4 \%$ of the GDP in 2017/2018; it also shows that Construction, Building, Electricity and Water, Real Estate, Extraction Industry and Petroleum consisted about $33.6 \%$ of GDP in 2017/2018.Despite the noticed expansion in these sectors, there is a decrease in the contribution of the sectors, that should be the main driver of growth, since the contributions of Agriculture and Manufacturing Industry decreased from 13.6\% and 15.5\% in 2008/2009 to $11.5 \%$ and $12.8 \%$ in $2017 / 2018$, respectively.

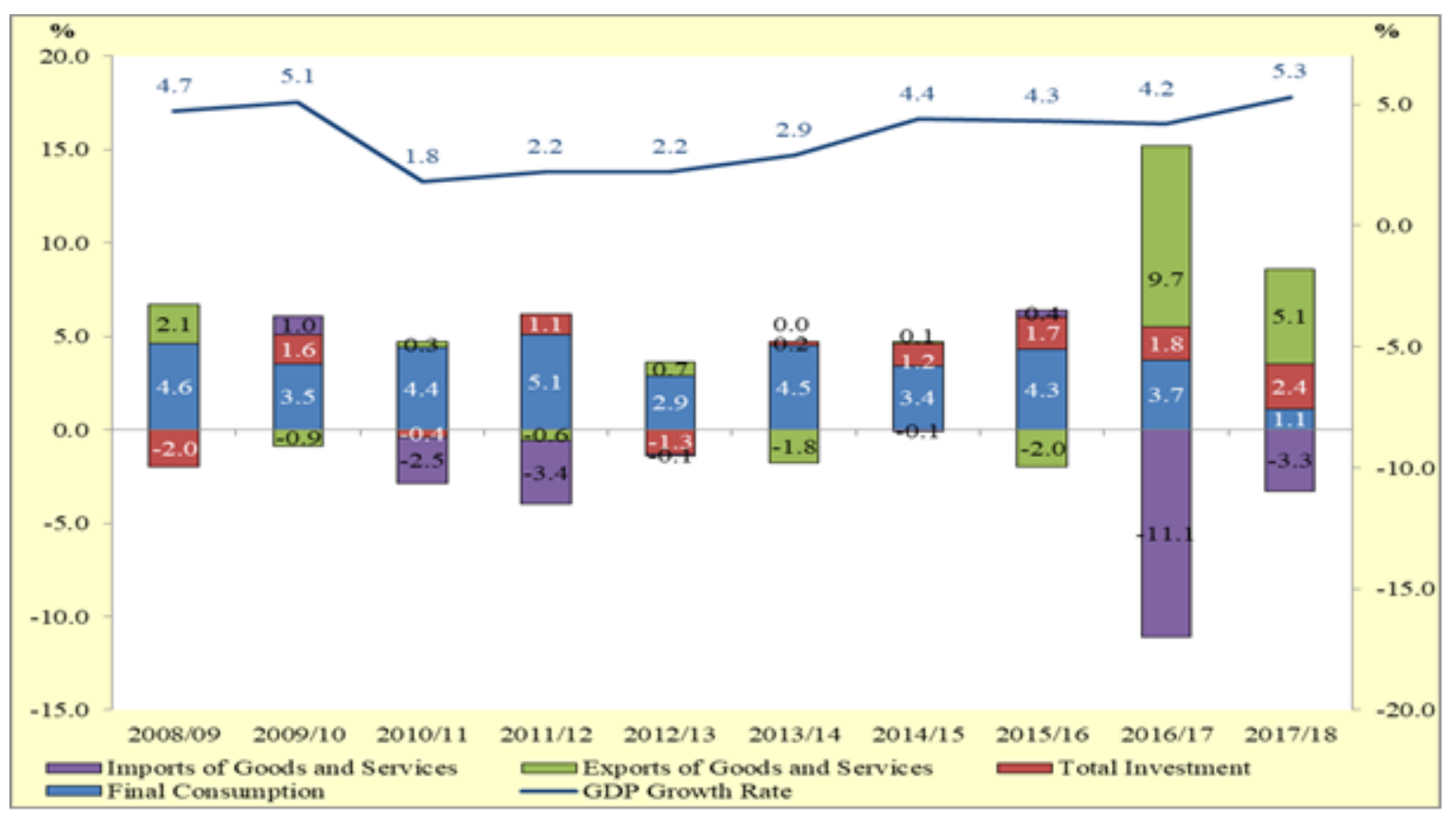

Figure 7. Contribution to GDP Growth from 2008/2009 to 2018/2019

The source of data: Arab Republic of Egypt Ministry of finance, The Financial Monthly Bulletin, Number of volumes. 


\section{$\Lambda$ Macrothink}

Business and Economic Research

ISSN 2162-4860

2019, Vol. 9, No. 4

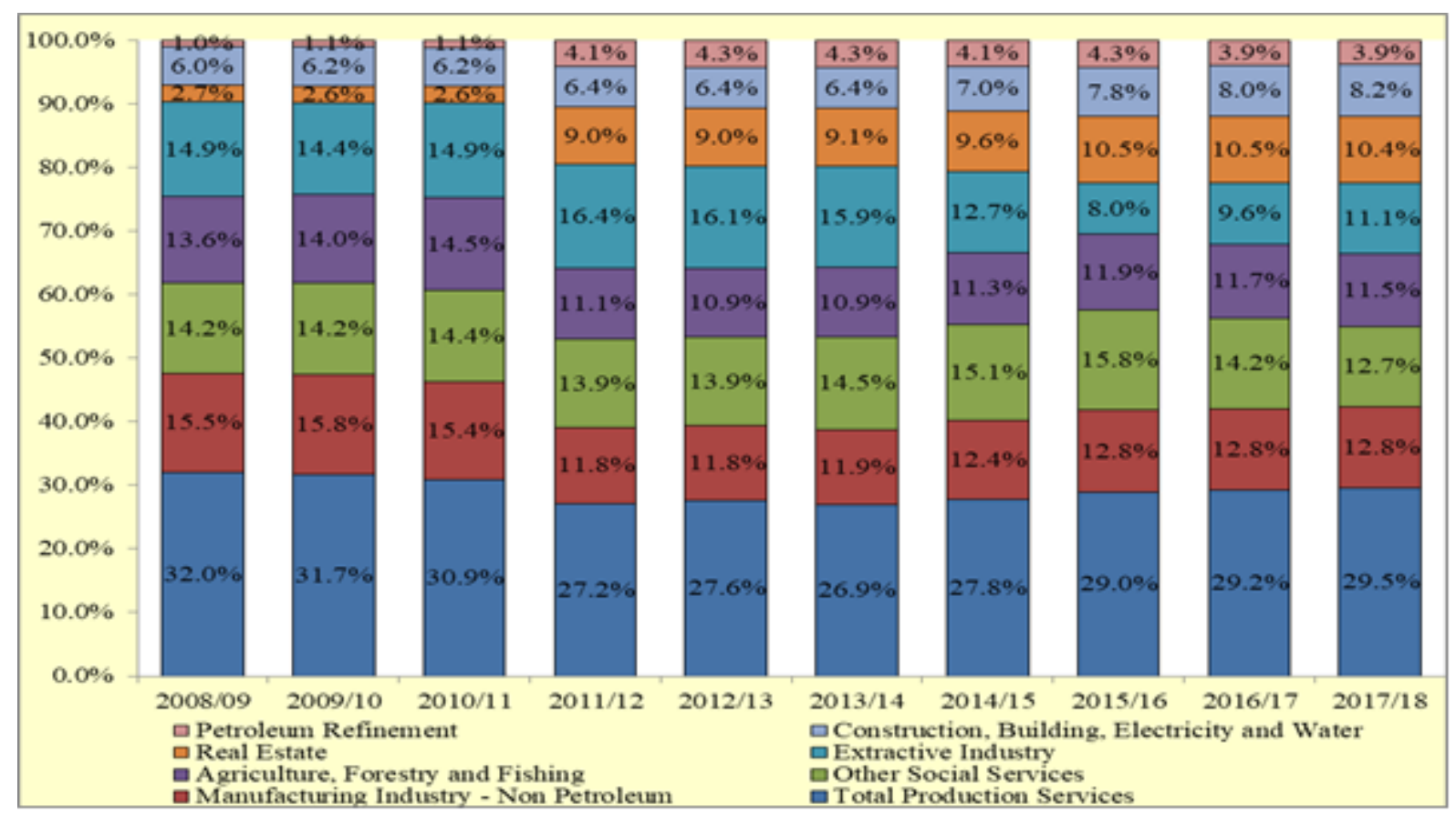

Figure 8. Contribution to GDP Growth (at factor cost) from 2008/2009 to 2018/2019

The source of data: Arab Republic of Egypt Ministry of finance, The Financial Monthly Bulletin, Number of volumes.

Therefore, there are many risks that challenge achieving the targeted 6\% GDP growth rate over the medium term, which is one of the main key items to drive Debt/GDP ratio to a sustainable down turn pass.

\subsection{Debt Roll Over Risk}

Despite the favorable impact of the economic reform program in narrowing the fiscal deficit, and the expected gradual reduction in debt level, there are many risks associated with Egypt's government ability to roll over its debt.

Egypt's government financing needs increased largely to exceed 50\% of GDP in the last 3 years. Figure (9) shows the difference between the gross financing need released by the government, and the gross financing needs adjusted by the research calculations; as follows:

Overall fiscal deficit + Principal payments $=$ Gross financing needs

Domestic debt + Foreign debt $=$ Principal payments 


\section{$\Lambda$ Macrothink}

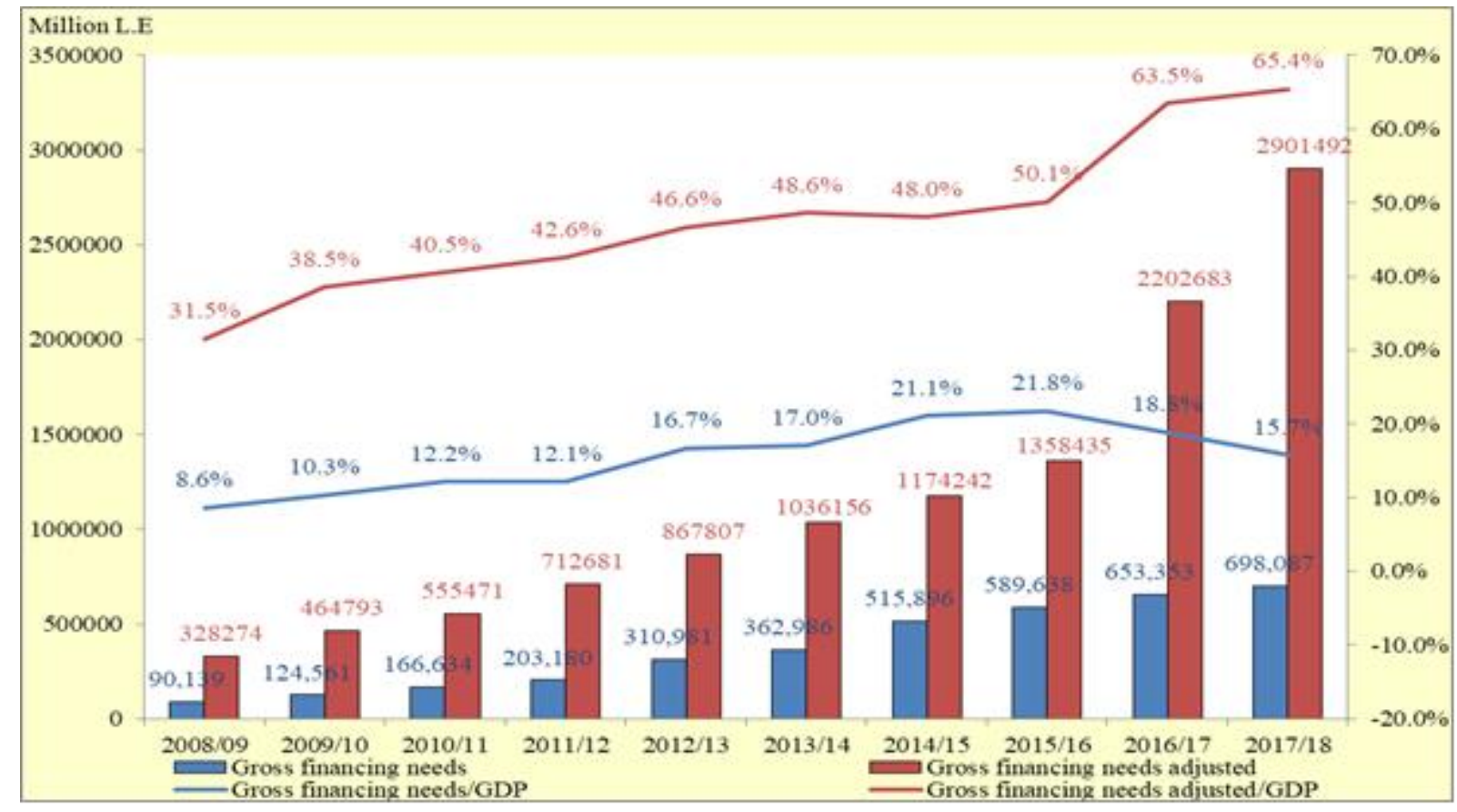

Figure 9. Gross financing needs from 2008/2009 to 2018/2019

The source of data: Arab Republic of Egypt Ministry of finance, The Financial Monthly Bulletin, Number of volumes.

In Egypt, the Domestic debt between the fiscal years 2008/2009 and 2017/2018 consists of the T-bills and T-bonds; so, the researcher replaced the principal payment of domestic debt by the matured government securities, to reflect the rollover of government securities during the year; which is not mentioned in the government estimates for financing needs.

Figure (9) shows that gross financing needs as percentage of GDP has grown so fast since the fiscal year 2008/2009 to 2017/2018, to represent about $65.4 \%$ of GDP; which is too high compared to the $10 \%$ threshold of the emerging countries.

Roll over risks persist due to the short maturity of government securities, since the T-bills of one year or less maturity represents about $47.5 \%$ of the gross domestic general government debt. Meanwhile, interest payments as a share of tax revenues is higher in Egypt compared to its peers in the region. (IMF, 2019).

On the other hand, Egypt is in a good position to manage any increase in capital outflows, while exchange rate risks still exist; since, the tightening in global financial conditions could pullback investors from emerging markets, and may lead to capital outflows, pressure on the external accounts, and higher borrowing costs, especially when foreigners hold a significant share of outstanding treasury bills (Moody's, 2016). 


\section{$\Lambda$ Macrothink}

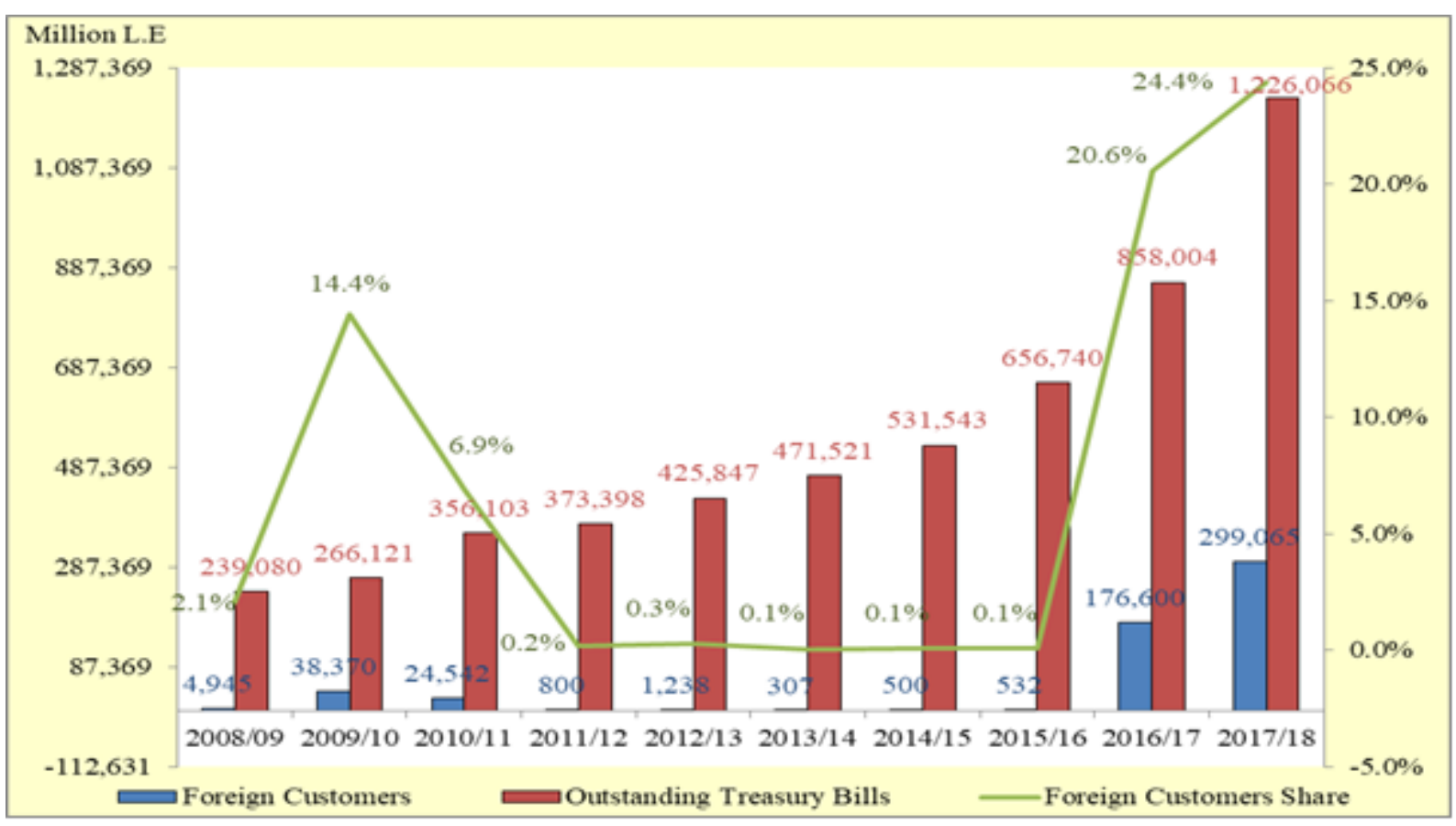

Figure 10. Outstanding treasury bills by holder from 2008/2009 to 2018/2019

The source of data: Arab Republic of Egypt Ministry of finance, The Financial Monthly Bulletin, Number of volumes.

Figure (10) shows that while the outstanding treasury bills increased over time, the share of foreign investors increased sharply in the last two fiscal years, to represent about $20.6 \%$ and $24.4 \%$ in 2016/2017 and 2017/2018, respectively. While the inflows from foreign investors might be very favorable to redeem the financial gap, it may also increase risks. Since, any increase in interest rate in advanced economies may lead to a serious drought out in public securities market.

\subsection{Contingent Liabilities}

Risks include any realization of contingent liabilities; such as, risks result from state-owned enterprises, government guarantees and pension system; as, it could increase public debt whenever any of it was materialized. However, it's difficult to conduct a comprehensive analysis about Egypt's government contingent liabilities, given the lack of reliable and consistent information. Since, the published data is only about the explicit debt of the government sector (Service Authorities and Central and Local Administrative Units), National investment bank, Economic authorities, Social insurance funds, and Monetary authorities (World Bank Group [WB], 2005).

The financial statement for the fiscal year 2018/2019 states that the preliminary data for contingent liabilities on public treasury in December 2017 represents about $19 \%$ to $20 \%$ of GDP, while the domestic guarantees represents about $8.7 \%$ of GDP, and the external guarantees represents about $10.4 \%$ of GDP. 
It's noticeable that the issued guarantees are concentrated in the sectors of energy and transportation (Egyptian General Petroleum Corporation, Electricity Companies, and Suez Canal Authority), since the guarantees to these entities represented about $84 \%$ of the outstanding guarantees (Mof, 2018).

\section{Systematic Approach towards Debt Reduction}

Despite the fact that fiscal consolidation will continue to be on the top of the fiscal agenda in Egypt over the coming years, applying budget caps, in addition to using top down approach in budget preparing, and using the fiscal rules, could help in narrowing the budget deficit. Since, there aren't much fiscal measures on the list to be applied; new supportive and non-stereotyped ideas should be applied to put public debt in Egypt on a downturn pass. In that regards, this part will include number of proposed ideas:

\subsection{Improve Tax Performance and Collection}

Taxes is considered the main source of revenues in Egypt, and it remained in the last decade broadly stable around $13.5 \%$ of GDP, which is well below the $14.7 \%$, the average of MENAP oil importers, and $16.7 \%$ the average of developing and emerging countries in 2016. This benchmarking shows that Egypt could raise tax revenues by 3 to $4.5 \%$ of GDP to create a room for social spending and invest in human and physical capital, in addition to further tax measures that could help in the repayment of the debt amount (Hanedar, 2017).

\subsubsection{Tax on Personal Net Wealth}

A one-time capital levy on net personal wealth could be one of the alternatives to refinance the severe increase in public debt in Egypt, and restore it on a downturn pass. This idea is gaining ground in a number of OECD countries, after the global financial crisis, when public debt to GDP ratio ballooned to a level that exceeded 100\% (Bach, Bezonoska, \& Steiner, 2014).

People affected of this wealth tax represent a very small share of all taxpayers, as net wealth is strongly concentrated at the top of the income distribution. High personal allowance should be granted, 5 Million LE is suggested with a fixed tax rate of 5\%, without exemptions on the net wealth. While there are a number of difficulties in compiling data on wealth, and to ensure that such measure achieves its objectives, it is assumed that the taxpayer who doesn't provide a tax declaration or provides wrong data should be sanctioned. However, the government should pledge not to apply such measures in the foreseeable future (Abul-Enein, 2016).

\subsubsection{Progressive Taxes}

Since the early 1980s taxes system has become steadily less progressive around the world; as, they rely more on indirect taxes that are less progressive than direct taxes. (IMF, 2013); this case is also applied in Egypt. As noted from table (4), Egypt has shifted gradually, over the last ten years, from reliance on direct taxes to indirect taxes. The share of income tax decreased from about $49.2 \%$ of total tax revenues in fiscal year 2008/2009 to only $32.9 \%$ in $2017 / 2018$, while the share of taxes on goods and services increased from $38.4 \%$ in the fiscal 
year $2008 / 2009$ to $46.8 \%$ in $2017 / 2018$.

Table 4. The Share of Different Taxes to Total Tax Revenues from 2009/2010 to 2017/2018

\begin{tabular}{|l|l|l|l|l|l|l|l|l|l|l|}
\hline & $2008 /$ & $2009 /$ & $2010 /$ & $2011 /$ & $2012 /$ & $2013 /$ & $2014 /$ & $2015 /$ & $2016 /$ & $2017 /$ \\
2015 & 2016 & 2017 & 2018 \\
\hline Income Tax & 2009 & 2010 & 2011 & 2012 & 2013 & 2014 & 2015 & $201 \%$ \\
\hline Property Taxes & $49.2 \%$ & $44.9 \%$ & $46.6 \%$ & $44.0 \%$ & $46.9 \%$ & $46.5 \%$ & $42.4 \%$ & $41.1 \%$ & $36.1 \%$ & $32.9 \%$ \\
\hline Taxes on Goods and Services & $1.7 \%$ & $5.1 \%$ & $4.9 \%$ & $6.3 \%$ & $6.6 \%$ & $7.2 \%$ & $6.9 \%$ & $7.9 \%$ & $7.9 \%$ & $8.2 \%$ \\
\hline Taxes on International Trade & $8.6 \%$ & $39.4 \%$ & $39.6 \%$ & $40.8 \%$ & $37.0 \%$ & $35.3 \%$ & $40.2 \%$ & $39.9 \%$ & $45.2 \%$ & $46.8 \%$ \\
\hline Other Taxes & $2.1 \%$ & $1.9 \%$ & $7.2 \%$ & $7.1 \%$ & $6.7 \%$ & $6.8 \%$ & $7.1 \%$ & $8.0 \%$ & $7.4 \%$ & $6.0 \%$ \\
\hline
\end{tabular}

The Source of data: Arab Republic of Egypt Ministry of finance, The Financial Monthly Bulletin, Number of volumes; Arab Republic of Egypt Ministry of finance: Analytical Separate Statement, 2019/2020.

Meanwhile, article (38) of the Egyptian constitution 2014 states that "Taxes imposed on the incomes of individuals are progressive multi-tier taxes that are imposed according to their tax capacity". In addition, the income tax law applied a progressive rate started form $10 \%$, as the lowest threshold on the annual income (7200 - 30000 L.E), to $22.5 \%$ as the highest threshold on income that exceeds (200000 L.E) (Waqaa Gazette, 2017).

Given large consolidation needs, a number of countries, since 2008; including, Greece, Iceland, Portugal, Spain, Ireland and The United Kingdom, have bucked the long trend of applying less progressive income tax by substantially increasing top personal income tax rate on average by more than $8 \%$ (IMF, 2013).

So, enhancing the progressiveness of personal income taxes by rising the rate of the highest threshold from $22.5 \%$ to $25 \%$, and introducing a new threshold for annual income that exceeds one million L.E, to be subject to $30 \%$ (specified to principle debt repayment), could be one of the appropriate alternatives to reduce the level of public debt, without affecting the economic growth and the standard of living in the society.

\subsection{Developing Government Securities Market}

Egypt's government securities market is one of oldest in the Middle East and Africa. The Egyptian government started, since the 1990s, to use T-bills to finance the budget deficit. In 2002, the primary dealers system was established by virtue of Minister of finance decree No. 480, and became effective in July 2004 (Mohamed, 2016).

The primary dealers system registers the authorized financial institutions with the Ministry of finance to allow them underwrite primary issues, and trade in government securities on the open market. Notification after the cases of purchase or sale in the open market is required. Currently, 15 banks were licensed and satisfied the requirements to deal with Egyptian treasury bills and bonds (OECD, 2006).

Although the main objective of the government securities market is to reduce the refinancing risks by lengthening the maturity structure of the domestic tradable debt, and consolidating a domestic yield curve, the market is still facing significant weaknesses: 
- The market is underdeveloped and the primary dealers are limited number of banks with a limited competition from other capital market participants (Arab Monetary Fund [AMF] \& European Bank for Reconstruction and Development, 2015).

- Primary markets provide an unbalanced choice of maturities, favoring longer term and liquid securities, instead of lengthening the yield curve and supporting secondary market liquidity.

- The secondary market is small and hindered, due to the lack of repo activities and institutional organization bottlenecks in the market.

- Clearing and settling the infrastructure need significant upgrades to be able to support more liquidity and be attractive to more investors (Garcia-Kilroy \& Silva, 2011).

To overcome these challenges, and satisfy the country's financing needs at a low cost and long term maturity, with a prudent degree of risk, the following market developments procedures should be applied:

- Allow non-banking financial institutions to be registered in the primary dealers system in order to diversify the investor base.

- Longer maturity instruments need to be issued through adding new instruments with longer maturities, as a new benchmark.

- Increase liquidity and enhance activities in the secondary market; the reopening of each security should be increased in order to raise the targeted amount.

- To avoid the crowding out of securities, the issuance weeks should be distributed as weeks for the issuance of T-bonds and others for T-bills, with different maturities.

- Developing and deepening the market infrastructure and introducing the repo activities (Mosler et al., 2017).

\subsection{Using the Appropriate Economic Policies Mix}

The significant rise in inflation rate in Egypt, after applying the economic reform program, was driven primarily by the supply side factor, as a result of the devaluation of the Egyptian pound, cutting energy subsidy, and the introduction of VAT. However, the CBE intervention to contain inflation was classic by increasing the interest rate.

This increase of the interest rate seems to be an inappropriate tool in the wrong time; especially that the main reasons behind this inflationary wave are supply factors; rather than demand factors. This increase of interest rate has a limited effect on curbing inflation and may not encourage large foreign direct investments within the current climate. Furthermore, it decreases private consumption and may become a disincentive to investment; especially small and medium investments, which may affect the economic growth negatively, in addition to the direct effect of rising interest rate and increasing the cost of financing. The chronic budget deficit made interest payment the biggest item of public spending, and redirected public borrowing to foreign resources. 
Regarding the previous analysis, relaxing the interest rate and using the appropriate economic policies that address the real sectors problems, would have a favorable impact on the economy. Since Egypt needs to increase productivity, and correct its growth and investment pattern through making productive sectors; especially agriculture and industry sectors, the main drivers of economic growth; rather than real estates and construction.

\subsection{Zero Interest on the Government Liabilities to the Central Bank of Egypt}

Figure (11) shows that government liabilities to the central bank has been growing steadily from 264.6 billion Egyptian pound in June 2012 to about 1 trillion Egyptian pound in June 2017, then it decreased slightly to 950.5 billion Egyptian pound in June 2018. Figure (11) also shows that government securities held by the CBE represents about three quarters of the government liabilities to the $\mathrm{CBE}$, while public bonds in local currency has the largest share (64.4\% in June 2018). In addition, figure (11) shows that the CBE also started to held government bonds in US dollars, starting from 2017, and endorses the deficit in the balance of government debit account through issuing bonds. It also shows that the devaluation of the Egyptian pound had a sharp effect on the government liability to the CBE, since the Ministry of finance account/foreign exchange net balances loss increased rabidly from 2.6 billion in June 2016 to 23.0 billion in June 2016, 206.2 billion in June 2017, and 191.1 billion in June 2018.

Figure (12) shows that interest payment to the CBE on government liabilities, has grown staidly from 21.7 billion Egyptian pounds in June 2012 to almost 100.2 billion in June 2018. Furthermore, it shows that although the government liabilities to the CBE decreased, between June 2017 and June 2018, the interest payment on these liabilities increased to reflect the fact of the growing financing needs to service the debt.

Meanwhile, the CBE holds about 23\% of general government debt in June 2018, and the interest paid on this debt represented about $22.9 \%$ of the total budget interest payment in June 2018. An agreement between the Ministry of Finance and the Central Bank of Egypt to sterilize this debt by issuing a bond at a zero rate, instead of the total government liability to the $\mathrm{CBE}$ repaid in installments, could have a positive impact on the fiscal position of the government, and the whole economic situation through the following: 


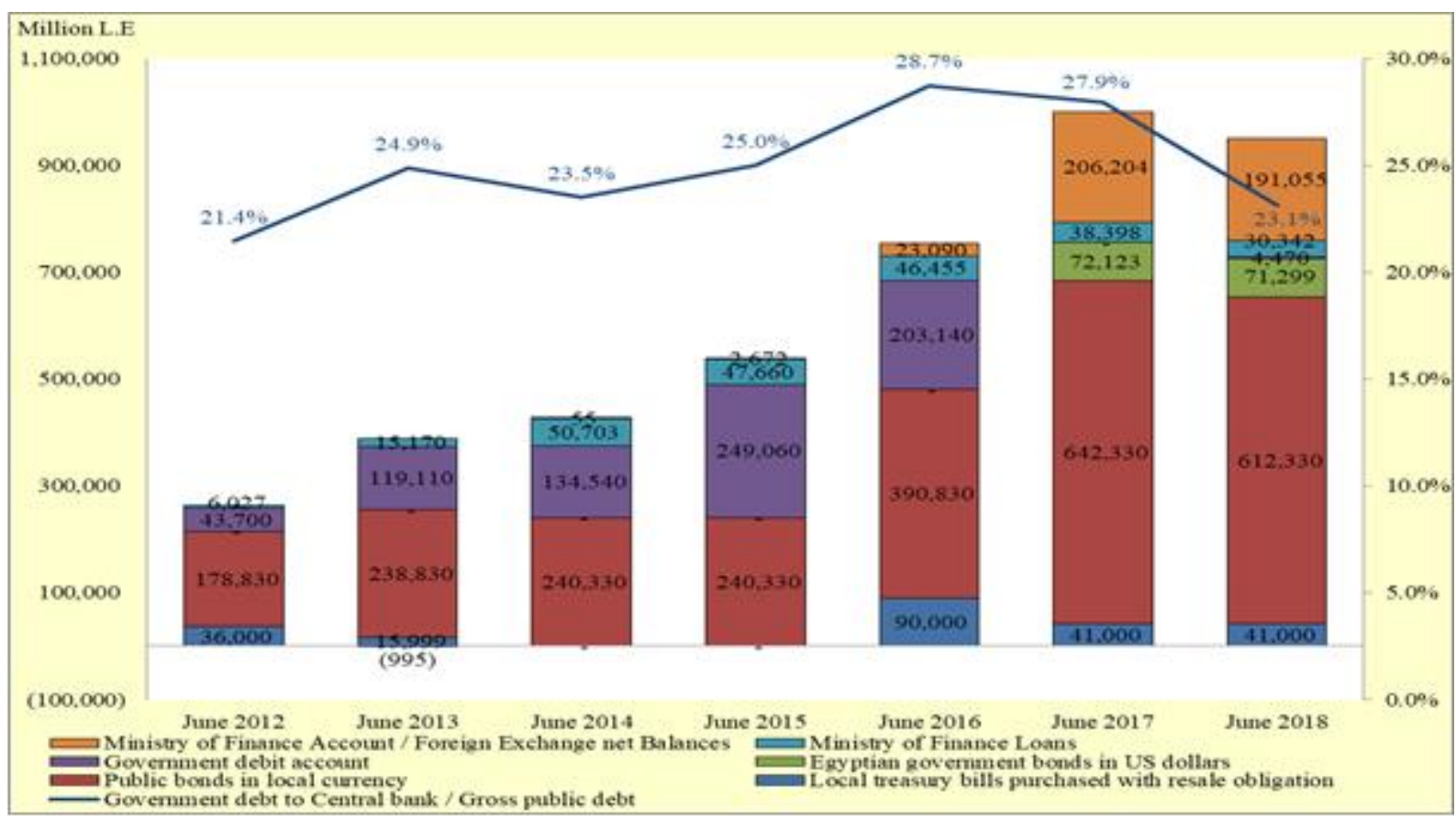

Figure 11. Government outstanding liabilities to CBE from June 2012 to June 2018

The source of data: Central Bank of Egypt, Audited Financial Statements, Number of volumes; Arab Republic of Egypt Ministry of finance, The Financial Monthly Bulletin, Number of volumes.

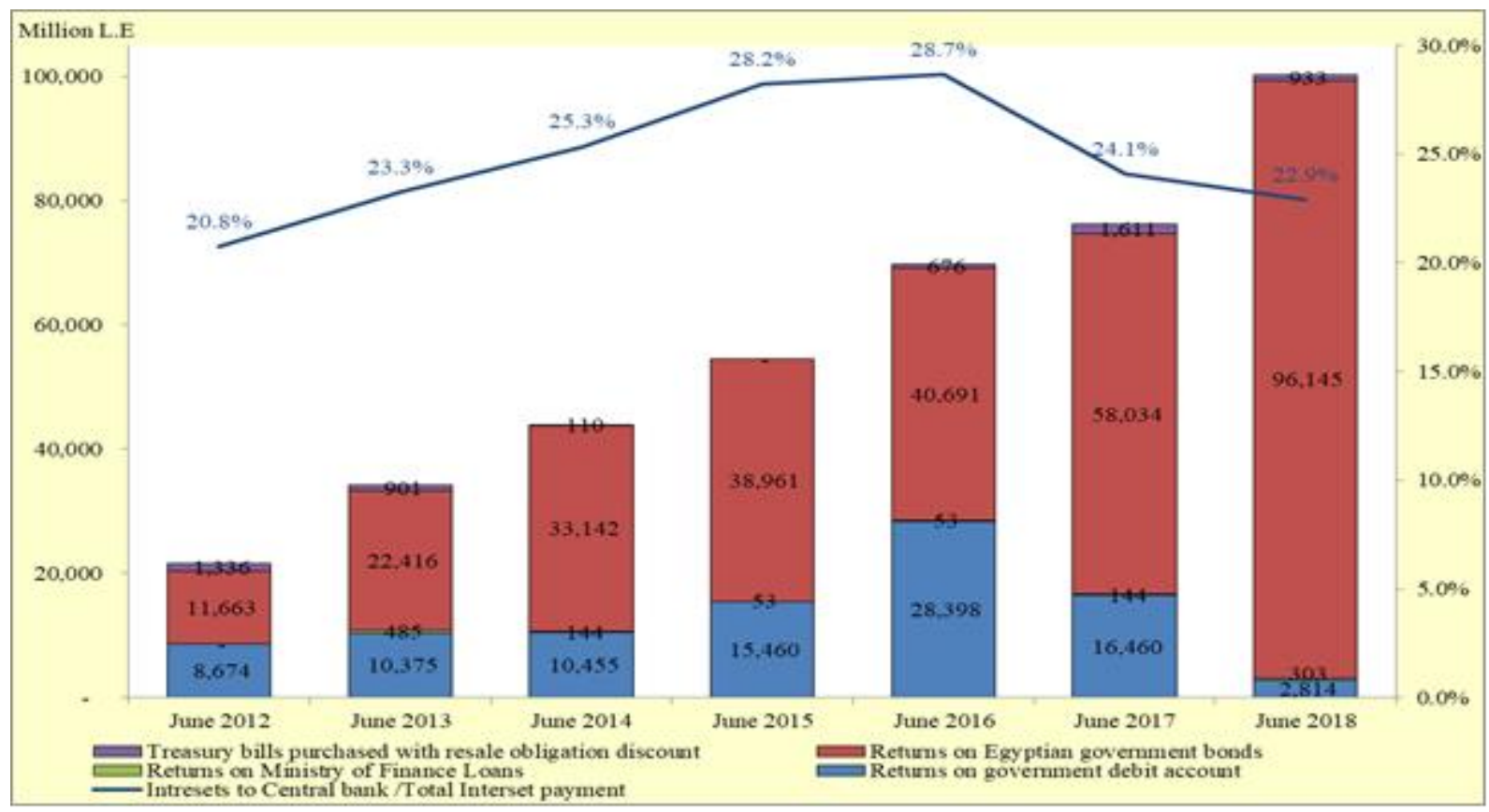

Figure 12. Interest payment to CBE on government liabilities from June 2012 to June 2018

The source of data: Central Bank of Egypt, Audited Financial Statements, Number of volumes; Arab Republic of Egypt Ministry of finance, The Financial Monthly Bulletin, Number of volumes. 


\section{Ml Macrothink}

Business and Economic Research

ISSN 2162-4860

2019, Vol. 9, No. 4

- The fiscal space resulted from such agreement, plus the primary surplus that started to materialize from the fiscal year 2017/2018, may help in facilitating debt repayment and extending this fiscal space.

- Such agreement will have a direct impact on decreasing both; the interest rate and the public treasury financing needs, which means a further decrease in interest payment and a wider fiscal space.

- The expected decrease in interest rate and public treasury financing needs will have a direct impact on the funding available to private sector, which indicates an opportunity for higher economic growth, and paves the way for a sustainable debt pass.

\subsection{Debt to Equity Swap}

As a result of the legacy of central planning era, the public treasury still controls a considerable equity in state owned companies, public enterprise sector companies, and banks, with various performance. Back to the end of 2018, the government announced its intention to list some profit making state owned companies in the stock market through the Initial Public Offering program (IPO).

Table 5. The Share of Different Taxes to Total Tax Revenues from 2009/2010 to 2017/2018

\begin{tabular}{|l|c|c|c|c|c|c|c|c|c|c|}
\hline & $\begin{array}{l}2008 / 2 \\
009\end{array}$ & $\begin{array}{l}2009 / 2 \\
010\end{array}$ & $\begin{array}{l}2010 / 2 \\
011\end{array}$ & $\begin{array}{l}2011 / 2 \\
012\end{array}$ & $\begin{array}{l}2012 / 2 \\
013\end{array}$ & $\begin{array}{l}2013 / 2 \\
014\end{array}$ & $\begin{array}{l}2014 / 2 \\
015\end{array}$ & $\begin{array}{l}2015 / 2 \\
016\end{array}$ & $\begin{array}{l}2016 / 2 \\
017\end{array}$ & $\begin{array}{l}2017 / 2 \\
018\end{array}$ \\
\hline $\begin{array}{l}\text { Dividends from State Owned } \\
\text { Companies (mn LE) }\end{array}$ & 20 & 165 & 0 & 838 & 598 & 754 & 1,070 & 1,145 & 2,506 & 2,412 \\
\hline $\begin{array}{l}\text { Dividends from Public Enterprise } \\
\text { Sector Companies (mn LE) }\end{array}$ & 3,873 & 3,099 & 3,263 & 2,987 & 2,911 & 2,362 & 2,191 & 2,272 & 2,722 & 4,443 \\
\hline Total Dividends & 3,893 & 3,264 & 3,263 & 3,825 & 3,509 & 3,116 & 3,261 & 3,417 & 5,228 & 6,855 \\
\hline Dividends/ Property Income (\%) & $7.3 \%$ & $6.0 \%$ & $7.9 \%$ & $6.8 \%$ & $6.2 \%$ & $5.5 \%$ & $4.0 \%$ & $4.9 \%$ & $5.7 \%$ & $9.9 \%$ \\
\hline Dividends/ Total Revenues (\%) & $1.4 \%$ & $1.2 \%$ & $1.2 \%$ & $1.3 \%$ & $1.0 \%$ & $0.7 \%$ & $0.7 \%$ & $0.7 \%$ & $0.8 \%$ & $0.8 \%$ \\
\hline
\end{tabular}

The source of data: Arab Republic of Egypt Ministry of finance: The Financial Monthly Bulletin, Number of volumes; Arab Republic of Egypt Ministry of finance: Closing Accounts, Number of volumes.

The IPO program aims to sell $15 \%$ to $30 \%$ of the equity of 20 companies and three banks through the stock market. The market value of these companies is about 430 billion Egyptian pounds, and the market value of shares that are expected to be listed in the stock market is about 80 billion Egyptian pounds. Among these twenty three entities, six are in the field of petrochemicals, four in petroleum, five in banking and financial sector, three in logistics, two in real estate, and two in manufacturing. The program is expected to be applied over twenty four to thirty months. The government's target through the IPO program is expanding ownership base, raising additional funds for the companies by attracting more investments from foreign and local markets, and optimizing the State's assets and its returns (Mof, 2018).

Table (5) shows that dividends that the public treasury receives from its equity in state owned companies and public enterprise sector companies, don't represent a significant part of the 
government revenues; since, they don't exceed $10 \%$ of the public treasury income from property, and at the same time, it's less than 1\% of the fiscal year 2017/2018 total revenues.

Despite the relevance of the IPO program objectives, it's possible to achieve the same objectives besides reducing the public debt level, and maintaining a controlling stake to the government in these companies through swapping the government's equity in some of the profitable state owned companies and public enterprise sector companies with the debt of the social Insurance Funds (SIF), and National Investment Bank (NIB).

\section{Study Limitations}

The paper focuses on introducing new supportive and non-stereotyped ideas that could be applied side by side to the traditional economic reform policies to put public debt in Egypt on a downturn and sustainable pass. The paper uses the analytical and descriptive approach, in addition to some statistical illustrations, to identify the magnitude of public debt problem in Egypt, asses the government plan of debt sustainability, and provides new supportive and non-stereotyped ideas to decrease the accumulating debt amount. However, due to the limited space of the paper, and the importance of analyzing the problem and introducing its specification, in addition to the importance of introducing these supportive ideas to deal with the problem as a package, the paper lakes to further statistical models to test and investigate the expected impact of these ideas. So, the researcher is planning to carry out additional studies to test and investigate the impact of these ideas using statistical models.

\section{Conclusion}

Due to the long-standing macroeconomic and fiscal imbalances that have been increasing since 25th of January 2011, public debt in Egypt reached a critical level when the government debt started to grow rapidly to record $103.1 \%$ of GDP in June 2017. To deal with this macroeconomic and fiscal imbalance, the government started to apply the economic reform program which was approved by the IMF in November 2016.

Despite the fact that the strong fiscal consolidation and steady economic growth have helped to put government debt to GDP ratio on a declining path to reach $92.5 \%$ in June 2018, the absolute amount of debt still accumulating, and the structure of debt became more risky; since the external debt component grew to $20.7 \%$, and the short-term debt became $47.5 \%$ in June 2018.

This fiscal imbalance, in addition to the negative changes in debt structure, had further implications on the debt services and gross financing needs. As interest payments represented $35.5 \%$ of total expenditure, and the gross financing needs grew to record $65.4 \%$ of GDP in the fiscal year 2017/2018.

In spite of the success of the government plan to debt sustainability in reducing the budget deficit to $9.8 \%$ of the GDP, and the public debt to $97 \%$ of the GDP in the fiscal year $2017 / 2018$, it failed to meet its declared targets in medium term debt management strategy (MTDS), and the five year macroeconomic framework and strategy (2014/15 - 2018/19). Furthermore, debt sustainability is subject to significant risks; such as, sustaining high 
economic growth rates, debt roll over risk, and the risk of materializing contingent liabilities.

In addition to the ongoing fiscal consolidation, other tools are needed to control and rationalize the public expenditure; as, there is a need to apply new and unconventional ideas to decrease the public debt and its burden and put the debt on a sustainable path.

These ideas are mainly about improving tax performance and collection through imposing tax on personal net wealth and enhancing progressive taxes system. The study also recommends developing the government securities market, using the appropriate economic policies mix, reaching an agreement with the Central bank of Egypt for a zero interest on the government liabilities, and swapping part of the public debt with a share of public treasury equity in state owned companies and public enterprise sector companies.

\section{References}

Abbas, A., Akitoby, M. B., Andritzky, M. J. R., Berger, M. H., Komastsuzaki, M. T., \& Tyson, J. (2013). Dealing with high debt in an era of low growth. International Monetary Fund, (No. 13-17). https://doi.org/10.5089/9781484316139.006

Abdel-Khalek, G. (2007). MIDG-based debt sustainability analysis: Egypt, country discussion. Joint UNDP/UNDESA initiative on defining a more MDG-consistent debt sustainability framework. [Online] Available:

https://www.undp.org/content/dam/aplaws/publication/en/publications/poverty-reduction/pov erty-website/mdg-based-debt-sustainability-analysis-egypt/MDG-basedDebtSustainabilityEg ypt.pdf

Abul-Enein, S. (2016). Taxes on wealth and capital gains "Concepts, possibilities and problems of application in Egypt", Policy Series, Institute of National Planning.

Alba, P., Al-shawarby, S., \& Iqbal, F. (2004). Fiscal and public debt sustainability in Egypt. Social and Economic Development Group, Middle East and North Africa Region, The World Bank, Working Paper Series No.38. [Online] Available:

http://web.worldbank.org/archive/website01418/WEB/IMAGES/WP38SEPT.PDF

Alnashar, S. (2019). Egypt Government Debt: Perpetual Deficits and Exchange Rate Depreciations. The World Bank. [Online] Available:

http://erf.org.eg/wp-content/uploads/2019/03/11-112-Sara-Alnashar.pd

AMF \& European Bank for Reconstruction and Development. (2015). Joint IFI needs assessment on Local capital market development (Egypt - Jordan - Morocco - Tunisia). Deauville Partnership. AMF \& European Bank for Reconstruction and Development. [Online] Available:

https://www.ebrd.com/documents/comms-and-bis/joint-ifi-needs-assessment-on-local-capitalmarket-development.pdf

Bach, S., Bezonoska, M., \& Steiner, V. (2014). A wealth tax on the rich to bring down public debt? revenue and distributional effect of a capital levy in Germany. Fiscal Studies, Institute for Fiscal Studies, John Wiley \& Sons Ltd, 35(1), 67-89. 
https://doi.org/10.1111/j.1475-5890.2014.12023.x

CBE. (2017). Monetary Policy Report, March 2017. CBE. [Online] Available:

https://www.cbe.org.eg/en/MonetaryPolicy/MonetaryPolicyReports/Monetary\%20Policy\%20 Report\%20March\%202017.pdf

CIB. (2019). Istethmar Fund Monthly Fact Sheet. CIB. [Online] Available:

https://www.cibeg.com/Arabic/Personal/Investments/Documents/CIB\%20Equity\%20Fund\%2 0MR\%20October\%202018.pdf

ElGhouty, A. (2018). Public debt and economic growth in Egypt. Business and Economic Research, Macrothink Institute, 8(3), 183-200. http;//doi.org/10.5296/ber.v8i3.13443

El-Mahdy, A., \& Torayeh, N. (2009). Debt sustainability and economic growth in Egypt. International Journal of Applied Econometrics and Quantitative Studies, 6(1), 26-55. [Online] Available: http://www.usc.es/economet/reviews/ijaeqs912.pdf

Fayed, M. (2012). Crowding Out Effect of Public Borrowing: The Case of Egypt. Faculty of Economics and Political Science, Economic Department, Cairo University.

Garcia-Kilroy, C., \& Silva, A. (2011). Reforming Government Debt Markets in MENA. Middle East and North Africa Region Financial and Private Sector Development Unit \& Financial and Private Sector Development Network Global Capital Markets Department, WB. Policy Research Working Paper 5611. [Online] Available:

http://documents.worldbank.org/curated/en/673921468052753217/Reforming-government-de bt-markets-in-MENA

Ghafar, A. (2018). A stable Egypt for a stable region: Socio-economic challenges and prospects. European Parliament.

Government of Egypt. (2015). Egypt's Five Year Macroeconomic Framework and Strategy FY 14/15 - FY 18/19. Egypt Economic Development Conference, Sharm El-Sheikh. Government of Egypt. [Online] Available:

http://www.mof.gov.eg/MOFGallerySource/English/Strategy.pdf

Hanedar, E. (2017). Arab Republic of Egypt Selected Issues: Tax Revenue Mobilization. IMF. [Online] Available: https://www.imf.org/ /media/Files/Publications/CR/2018/cr1815.ashx

IMF. (2013). Fiscal Monitor October 2013. IMF. [Online] Available:

https://www.imf.org/ /media/Websites/IMF/imported-flagship-issues/external/pubs/ft/fm/201 3/02/pdf/_fm1302pdf.ashx

IMF. (2013). Staff guidance note for debt sustainability analysis in market assess countries. IMF. [Online] Available: https://www.imf.org/external/np/pp/eng/2013/050913.pdf

IMF. (2015). Arab Republic of Egypt, Staff Report for the 2014 Article IV consultation. IMF. [Online] Available:

https://www.imf.org/ /media/Websites/IMF/imported-full-text-pdf/external/pubs/ft/scr/2015/ _cr1533.ashx 
IMF. (2016). IMF Executive Board Approves US\$12 billion Extended Arrangement Under the Extended Fund Facility for Egypt. IMF. Press Release No.16/501. [Online] Available:

https://www.imf.org/ /media/Files/Publications/CR/2017/cr1717.ashx

IMF. (2018). Fiscal Monitor April 2018. IMF. [Online] Available:

https://www.imf.org/ /media/Files/Publications/fiscal-monitor/2018/April/pdf/fm1801.ashx

IMF. (2018). Review Under The Extended Arrangement Under the Extended Fund Facility for a Waiver of Non observance of a Performance Criterion and For Modification of a Performance Criterion - Press Release; Staff Report; and Statement by the Executive Director For The Arab Republic of Egypt. IMF. Country Report No.18/213. https://doi.org/10.5089/9781484366998.002

IMF. (2019). Arab Republic of Egypt, Fourth review under the extended fund facility. IMF. Country Report No.19/98. https://doi.org/10.5089/9781513516622.002

Iradian, G., \& Rosenthal, J. (2018). Reasons for Optimism, but Challenges Remain, Country Report: Egypt. Institute of International Finance. [Online] Available:

http://enterprise.press/wp-content/uploads/2018/11/32370132_final_egypt_report_october_20 18-1.pdf

Massoud, A. (2014). Dealing with the increasing public debt in Egypt. International Journal of Social Science Studies, Redfame Publishing, 3(1), 17-29.

http://dx.doi.org/10.11114/ijsss.v3il.593

Mof. (2015). Medium-Term Debt Management Strategy (MTDS). Mof. [Online] Available: http://www.mof.gov.eg/MOFGallerySource/English/PDF/Medium-Term_Debt_Management _Strategy.pdf

Mof. (2018). Financial Statement for the fiscal year 2018/2019. Mof. [Online] Available: http://www.mof.gov.eg/MOFGallerySource/Arabic/budget2018-2019/Financial-Statement-20 18-2019.pdf

Mof. (2019). Analytical Separate Statement 2019/2020. Mof. [Online] Available:

http://www.mof.gov.eg/MOFGallerySource/Arabic/budget2019-2020/Financial-Statement-20 19-2020.pdf

Mohamed, S. (2016). Coordination of Monetary and Fiscal Policies: The Case of Egypt. International Review of Research in Emerging Markets and the Global Economy (IRREM), 2(4). [Online] Available:

http://globalbizresearch.org/files/df606_irrem_sahar-mohamed-abdel-haleim-416692.pdf

Moody's. (2016). Government of Egypt - B3 Stable, Annual Credit Analysis. Moody's. [Online] Available:

https://enterprise.press/wp-content/uploads/2016/09/moodys-_government_of_egypt-_annual _credit_analysis-report_28_sept_2016.pdf

Mosler, M., Potrafke, N., Reischmann, M., Riem, M., Schönherr, S., Schulze, G., Steiner, A., ... Wollmershäuser, T. (2017). Improving Public Debt Management in the OIC Member 
Countries. COMCEC. [Online] Available:

http://www.comcec.org/en/wp-content/uploads/2017/04/8-FIN-AN.pdf

Mossallem, M. (2017). Egypt's debt trap: The neoliberal roots of the problem. Committee for the Abolition of Illegitimate Debt (CADTM). [Online] Available:

http://www.cadtm.org/Egypt-s-debt-trap-The-neoliberal

OECD. (2006). Egypt national investment reform agenda workshop, Financial markets session: Improving capital market mechanisms, MENA-OECD Investment Programme. OECD. Draft Background Paper. [Online] Available:

http://www.oecd.org/mena/competitiveness/36807522.pdf

OECD. (2013). Government at a Glance 2013. OECD Publishing.

https://doi.org/10.1787/gov_glance-2013-en

Pescatori, A., Sandri, D., \& Simon, J. (2014). Debt and growth: Is There a magic threshold? IMF, IMF Working Paper, WP/14/34. https://doi.org/10.5089/9781484306444.001

Reinhart, C., Reinhart, V., \& Rogoff, K. (2015). Dealing with debt. John F. Kennedy School of Government, Harvard Kennedy School, RWP15-009. https://doi.org/10.2139/ssrn.2577359

Unctad. (2018). Financing for development: Debt and debt sustainability and interrelated systemic issues. Trade and Development Board Intergovernmental Group of Experts on Financing for Development, Second session, Geneva, 7-9 November 2018. [Online] Available: https://unctad.org/meetings/en/SessionalDocuments/tdb_efd2d2_en.pdf

Waqaa Gazette. (2017). Law No. 82 of 2017 issued. Waqaa Gazette. vol. 24 bis (c) dated 21/6/2017.

WB. (2005). Fiscal and public debt sustainability, Egypt Public Expenditure Review. WB. [Online] Available:

http://www.mof.gov.eg/MOFGallerySource/English/policy-notes/Fiscal\%20and\%20Public\%

20Debt\%20Sustainability\%20-\%20July\%202005.pdf

CBE. Audited Financial Statements. Number of volumes. $C B E$.

CBE. External Position of the Egyptian Economy. Number of volumes. $C B E$.

CBE. Monthly Statistical Bulletin. Number of volumes. CBE.

Mof. Closing Accounts. Number of volumes. Mof.

Mof. The Financial Monthly Bulletin. May 2018. Mof.

Mof. The Financial Monthly Bulletin. Number of volumes. Mof.

Mop. Database. Mop. 


\section{Copyright Disclaimer}

Copyright for this article is retained by the author(s), with first publication rights granted to the journal.

This is an open-access article distributed under the terms and conditions of the Creative Commons Attribution license (http://creativecommons.org/licenses/by/3.0/). 